\title{
THE NATIVITY OF SAINT NICHOLAS TROPARIA AND KONTAKIA IN RUSSIAN HANDWRITTEN AND PRINTED SOURCES
}

Summary: The present article emerged due to fortunate circumstances. It happened that an intact notation of a troparion to the Nativity of Saint Nicholas "Chudnoe i slavnoe rozhdestvo tvoe..." was found in the $17^{\text {th }}$ century manuscript from the compendium of Archbishop D. Razumovskiy in the Russian State Library, fund 379, №66. The troparion itself is written in the form of the znamenny chant using kryuki (znamennaya notation). To date, the notation is the only record of both troparion and hymnography to the Nativity of Saint Nicholas.

The article provides the chant in its original form "istinno pravoslavnoy melodii - spasitelnoy i dushepoleznoy" [its truly orthodox melody - salutary and edificatory], as Archbishop Boris Nikolaev ${ }^{1}$ talks about the znamenny chant. In conjunction with this, the author of the article presents a conversion from bespometnaya notation based on kryuki into a five-line one. The process is conducted based upon the analysis of popevkis from dvoeznamenniks dating from the $18^{\text {th }}$ century, as well as upon litsas and fitas of M.Brazhnikov². The conversion of bespometnaya notation is given in the form of a hypothesis of how the chant would sound with a view to a scientific discussion.

The publication is preceded by brief research of troparia and kontakia of the feast day and their content and status in Russian handwritten and printed sources. These issues are of utmost importance to both fellow citizens and religious practices when it comes to rediscovering the chants to The Nativity of Saint Nicholas. Therefore, troparia and

1. Nikolaev Boris, Archbishop. Znamennyi Chant and Kryuki Notation as the Foundation of Russian Orthodox Liturgical Chant. Experience in the Study of Melodics and Notation of Russian Orthodox Liturgical Chant from the Church Liturgical Perspective / Joseph-Volokolamsk Monastery, Old-Russian Society of Musical Culture. Moscow, Talan Publishing house, 1995. P. 31.

2. Brazhnikov M.V. Litsas and Fitas of the Znamennyi Chant: Research / ed. N.Seregina, A.Kryukova; Preface by N.Seregina. Leningrad: Muzyka. Leningrad department, 1984. Pp. 112-120. kontakia are introduced in their entirety. These are nine heritages of Russian hymnography in the sources during the late $16^{\text {th }}-19^{\text {th }}$ centuries.

Keywords: hymnography, troparion, kontakion, the Nativity of Saint Nicholas, hagiography and miracles, znamenny chant, bespometnaya notation.

In contemporary history, the feast of the Nativity of St. Nicholas became known from the printed Menaia of $1978-1989^{3}$. This series of liturgical books was prepared with the blessing of His Holiness Patriarch of Moscow and All Russia Pimen for the solemn celebration of the $1000^{\text {th }}$ anniversary of the Baptism of Rus.

The publication is unique in terms of the number of collected together Russian memoirs and hymnography compared to those printed books that were known before ${ }^{4}$. Head of the Publishing Department of the Moscow Patriarchate, Archimandrite Innokenty (Prosvirin), wrote: "The new edition of the Menaia brings to life the ideas of many generations of Russian people who have sought to convey, in one handwritten form or another, the Russian tradition about their saints who make up the imperishable structure of the Church" ${ }^{5}$.

3. Service Menaion. July: Part 3. Moscow: Moscow Patriarchate. 1988. P. 297.

4. Menaia: an Example of Hymnographic Literature and a Means of Forming the Orthodox Worldview / ed. E.Potekhina and A.Kravetsky. Olsztyn, 2013. Pp. 36-42.

5. Service Menaion. September. Moscow: Moscow Patriarchate. 1978. P. 7. 
In their work, the employees of the Publishing Department of the Moscow Patriarchate, chaired by Metropolitan Pitirim (Nechaev), relied on the works of the Liturgical and Calendar Commission of the Holy Synod in 1953-1958, which was headed and inspired by St. Afanasy (Sakharov). The commission, in turn, with the blessing of His Holiness Patriarch Alexy I, carried out the decisions of the Local Council of 1917-1918 ${ }^{6}$. Thus, the Menaia of 1978-1989 summed up the experience of researchers and collectors of Russian liturgical works of the last century.

The publication of the Liturgical Menaia summarized the achievements of the last century as much as possible and served as a starting point for research in the present century. It has become the criterion with which scientists in different areas of the Old Russian tradition - hymnography, eortology, hagiography, iconography, correlate their work. The Pimenov Menaia (as they are called in everyday life) were repeatedly supplemented. On their basis, the following editions were compiled. With the blessing of the Patriarch of Moscow and All Russia, Alexy II, a series of Menaia was published from September to August (2002) as well as the Additional Menaion in two volumes (2005). With the blessing of the Patriarch of Moscow and All Russia, Kirill, the new Supplementary Menaion was published in two volumes (2018).

The feast of the Nativity of St. Nicholas, Archbishop of Myra in Lycia, has been in the Menaia since the 1978-1989 edition. In "the month of July on the 29th day", the troparion tone 4: "Chudnoye i slavnoye rojdestvo tvoye..." [Your wonderful and glorious birth...] and the kontakion tone 2: $\mathrm{V}$ Mireh Svyate "V Mireh rojdesya svyate Nikolaye..." [in Myra, Saint Nicholas was born...] were written out. At the beginning of the $20^{\text {th }}$ century, another printed edition contained a text in memory of the Nativity of the Saint. This is "Mesyacelov svyatih vseiu Russkoiyu Tserkoviu ili mestno chtimih <...>" [Menologium of the Saints of the All Russian Church or Locally Revered] compiled by Archbishop Dimitri (Sambikin). The Menologium was published in 1901 "with the blessing of the local diocesan authorities" as an appendix to the Tver Diocesan Journal ${ }^{8}$. In

6. Semenenko-Basin I. V. Worshiping of Russian Saints: a Project of Afanasiy Sakharov in Historical Context // Krasnodar: Publishing house of Krasnodar State Cultural Institute. 2009, pp. 61-63.

7. Service Menaion. July ... p. 297

8. Sambikin Dmitry, Archbishop, Menology of Saints Worshiped by Both Russian and Local Churches, as well Being a Calen- the bibliography of the feast of the Nativity of St. Nicholas, the Menaion 1978-1989 compilers refer to this source; the same troparion and kontakion are published in it ${ }^{9}$.

We do not know of any other printed liturgical books in which the feast of the Nativity of St. Nicholas is present ${ }^{10}$. Until the $20^{\text {th }}$ century, the tradition of the celebration was passed down in manuscripts.

The handwritten history of the holiday spans seven centuries - from the $13^{\text {th }}$ to the $19^{\text {th }}$ centuries. In the $13-15^{\text {th }}$ centuries, the Nativity of St. Nicholas is mentioned in Bulgarian and Russian church calendars ${ }^{11}$. The hymnography of the holiday has been recorded in Russian sources since the $16^{\text {th }}$ century. These are both individual chants and liturgical prayers - services with festive stichera and canon. Russian services to the Nativity of St. Nicholas were described in the article of the same name ${ }^{12}$.

dar for Festivities in Honor of the Icon of Divine Mother and God's Saints in our Homeland: Vol. 1-12 (in 14 volumes). Publishing house of the provincial government, 1893-1902. Issue 11: July. 1901, p. 342.

9. The research of printed books was carried out according to the list presented in the book: A.S.Zernova. Books of Cyrillic Printing Published in Moscow in the $18^{\text {th }}-19^{\text {th }}$ Centuries. Ministry of culture of the Russian SFSR, V.I.Lenin State Library of the USSR, Rare Books department. Moscow: Publishing house of the State Library of the USSR. 1958. P. 150.

In scientific descriptions of manuscripts, there are indications of the printed source. For example, in the description of the Collection of Handwritten Books by N.Tikhonravov (Moscow, 1977), it is written: "F. 299, No. 484.1, 1723, Collection of hagiographies, Miracles of St. Nicholas and services to him. Without beginning and end. A list from printed? "; in the description of the Collection of Manuscript Books by A.Markushevich (Moscow, 1982), it is indicated: "F. 755, No. 16, Church calendar (list from the publication of M., 1648) and the Charter in the Christian life». However, when comparing handwritten and printed sources (in those cases where they are indicated), it turned out that the memories of the Nativity of St. Nicholas are not found in the printed editions.

10. Spassky Sergius, Archbishop. Full Menology of the East: In 3 volumes / V. 2: Holy East. Moscow: Publishing house of theological scholarly venue «Orthodox Encyclopaedia»: Orthodox Piligrim. 1997. P. XXIII, 137. Loseva O. V. Russian Menology of the $11^{\text {th }}-14^{\text {th }}$ Centuries. Moscow: Pamyatniki Istoricheskoy Mysli Publishing house. 2001. Pp. 123, 413.

11. Cherkasova S.A. Russian Church Services in Worshiping of Saint Nicholas. Moscow, Alpha I Omega Publishing house: 2008. No. 1 (51). Pp. 285-298.

12. In studying the manuscript tradition, we relied on the corpus of materials from the Department of Manuscripts of the Russian State Library. Books of various types, in which not only hymnography but any mention of the holiday could be contained: menologies, horologions, church calendars, charters, psalms, iconographic originals, collections and singing manuscripts, were looked through. For each Collection of Manuscripts of the RSL, a list of sources of eortology and hymnography of the Nativity of St. Nicholas was compiled.

The starting point for us was «A List of Manuscripts with Works about St. Nicholas in the Collection of the RSL», compiled by M.Krutova. Among the works of hagiography, the List contains 
The current work is about the main chants of the holiday - the troparia and kontakia ${ }^{13}$.

In handwritten sources of the $16-19^{\text {th }}$ centuries, there are altogether nine chants of troparia and kontakia. Below is the list of them starting with the earliest text:

Troparion tone 4

"Otechestvo svoye i rojenie i vospitaniye..."

(F. 209, No. 390, $16^{\text {th }}$ century, Charter)

Troparion tone 4

"Preslavnomu rojdestvu tvoemu angelstii

chinove..." (F. 199, No. 118, 1615, Church calendar)

Troparion ${ }^{14}$ tone 2

"Tserkvi tvoya Gospodi svetlo prazdnuiut..." (F. 199, No. 118, 1615, Church calendar)

Troparion tone 4

"Taino derznovenne upodobilsya yesi mudre..." (F. 98, No. 209, $17^{\text {th }}$ century (before 1606) Charter)

Troparion tone 4

"Chudnoye i slavnoye rojdestvo tvoye..."

(F. 379, No. $66,17^{\text {th }}$ century, the Menaion JuneAugust, kryuki)

\section{Troparion tone 2}

"Dnes vozsya nam yako solntse torjestvo tvoye..." (BAN Vyatka collection, №66, $18^{\text {th }}$ century, Collection of church services)

\section{Kontakion tone 3}

"Vzde yako zvezda ot vostoka i do zapada tvoe rojenie i vospitanie..." (F. 209, No. 390, 16 $6^{\text {th }}$ century, Charter)

two manuscripts with services to the Nativity of St. Nicholas. See: M.Krutova St. Nicholas the Wonderworker in Old Russian Writing. Moscow: Martis Publishing house, 1997. P. 152.

13. We would like to thank the head of the Liturgical Heritage of the Orthodox Church Project for the help in the source study, O.Ladu. For more details on the project, see: A.Kositskaya, J.Levshina. Area Orthodoxa Gymnography in the Liturgical Heritage of the Orthodox Church Project. Goals and Objectives of the Project. Archeography and Source Study // Staroblgarsk literature, book. 47, 2013. Pp. 391-406.

14. In the manuscript, it is designated as «kontakion tone 2». Written before this text, kontakion «V mireh rojeisya...» is designated as «another troparion tone 2». Probably, the scribe confused and changed the places of the texts « $V$ mireh rojeisya...» and «Tserkvi tvoya Gospodi...». Thus, the text «Tserkvi tvoya Gospodi...» should be designated as «another troparion tone 2» - this is correct. The text " $V$ mireh rojeisya..." should be designated as "kontakion tone 2 " - this is correct. The error has been corrected in the list of texts given in the article.
Kontakion tone 2

" $V$ mireh rojeisya svyatii Nikolaye ot blagorodnogo kornya..." (F. 199, No. 118, 1615, Church calendar)

Kontakion tone 3

"lakoje $v$ rojdestve vozsial yesi Duhom Presvyatim...." (F. 199, No. 457, 17 th century, Charter)

Troparia and kontakia are found in manuscripts in different combinations. For example, kontakion tone 2 "V mireh rojeisya svyatii Nikolaye..." is written out with all known troparia ${ }^{15}$; kontakion tone 3 "Vzde yako zvezda ot vostoka i do zapada tvoe..." only with the troparion tone 4 "Otechestvo svoye $i$ rojenie i vospitaniye..."; troparion tone 4 "Preslavnomu rojdestvu tvoemu angelstii chinove..." together with another troparion tone 2 "Tserkvi tvoya Gospodi svetlo prazdnuiut..." etc. We looked at the chants from the point of view of content. From this perspective, troparia and kontakia can be combined into three groups $^{16}$.

The first one includes texts based on St. Nicholas' hagiography, named after its author "Metaphrastovo". "The hagiography was written by byzantine hagiographer, St. Simeon Metaphrast, in the $10^{\text {th }}$ century. This type of hagiography $\langle\ldots\rangle$ is included in the Great Menaion Reader by St. Macarius, Metropolitan of Moscow and All Russia"17.

The second group of chants is based on the so-called "inoye" [other] hagiography. This type of hagiography also belongs to the Greek hagiographic tradition. "In Russia, the text has been known since the $11^{\text {th }}$ century. Some scholars believed that it was translated into Russian by St. Efrem Pechersky, Bishop of Pereyaslavl" ${ }^{18}$.

The third group is hymnography, which is compiled based on the Russian experience of reverence of St. Nicholas. Its content conveys the most general but important for Russian spiritual creativity images and thoughts; our Christian culture's history is reflected in it.

We will sequentially tell about the chants of each conventionally designated group.

15. In addition to the troparion tone 4 «Otechestvo tvoye $i$ rojdeniye $i$ ospitaniye...», which is written out with a kontakion tone 3 "Vzide yako zvezda ot vostoka i do zapada tvoye rojeniye $i$ vospitaniye...".

16. It should be stressed that the division into groups is conditional. It was done as part of the study.

17. For information on hagiography and publications of different types of hagiography of St. Nicholas see: M.Krutova, Same work.

18. Ibid. Pp. 120-127. 
"Chudnoe i slavnoe rozhdestvo tvoe"

The Nativity of Saint Nicholas Troparion tone 4
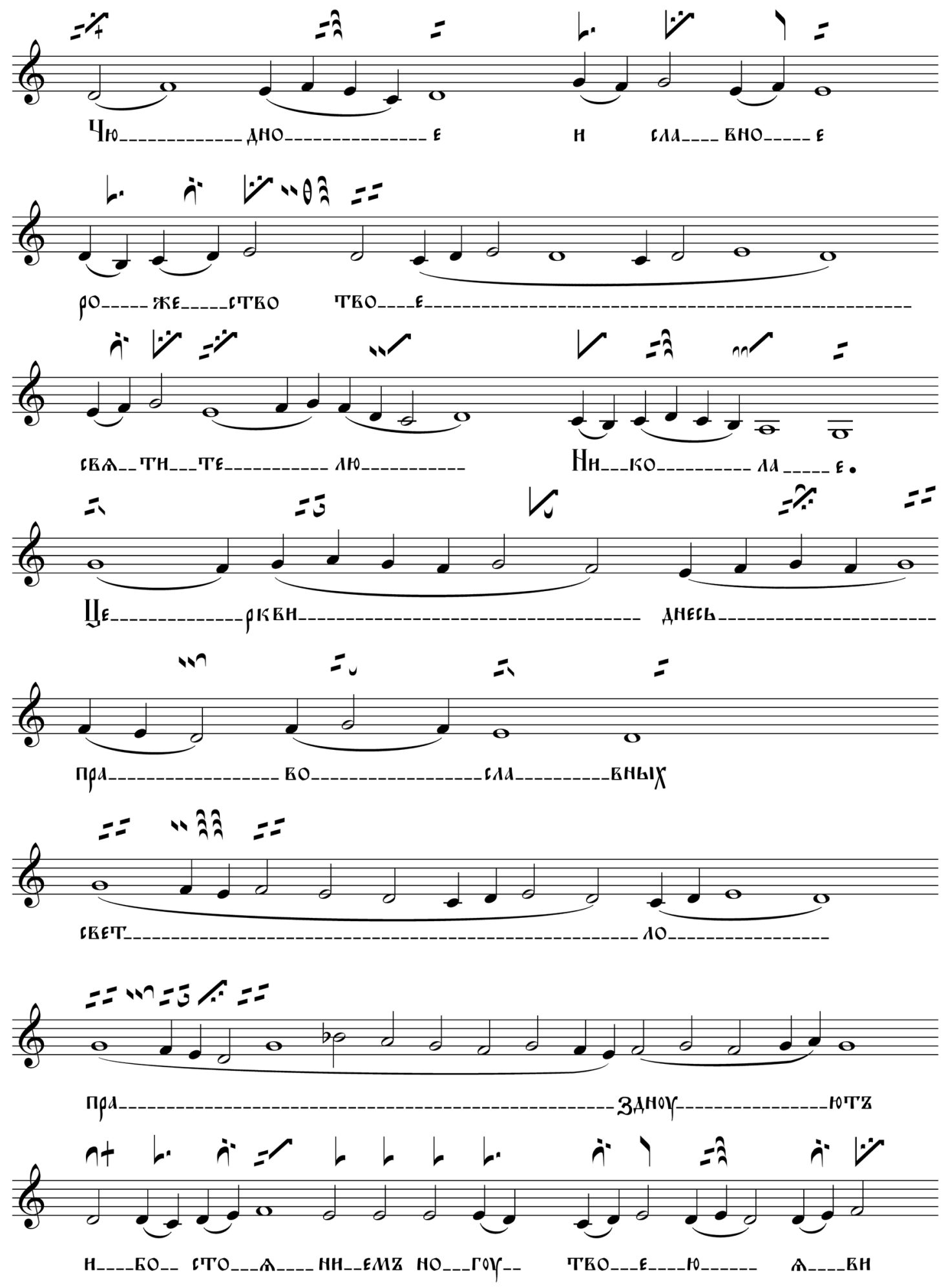

36 

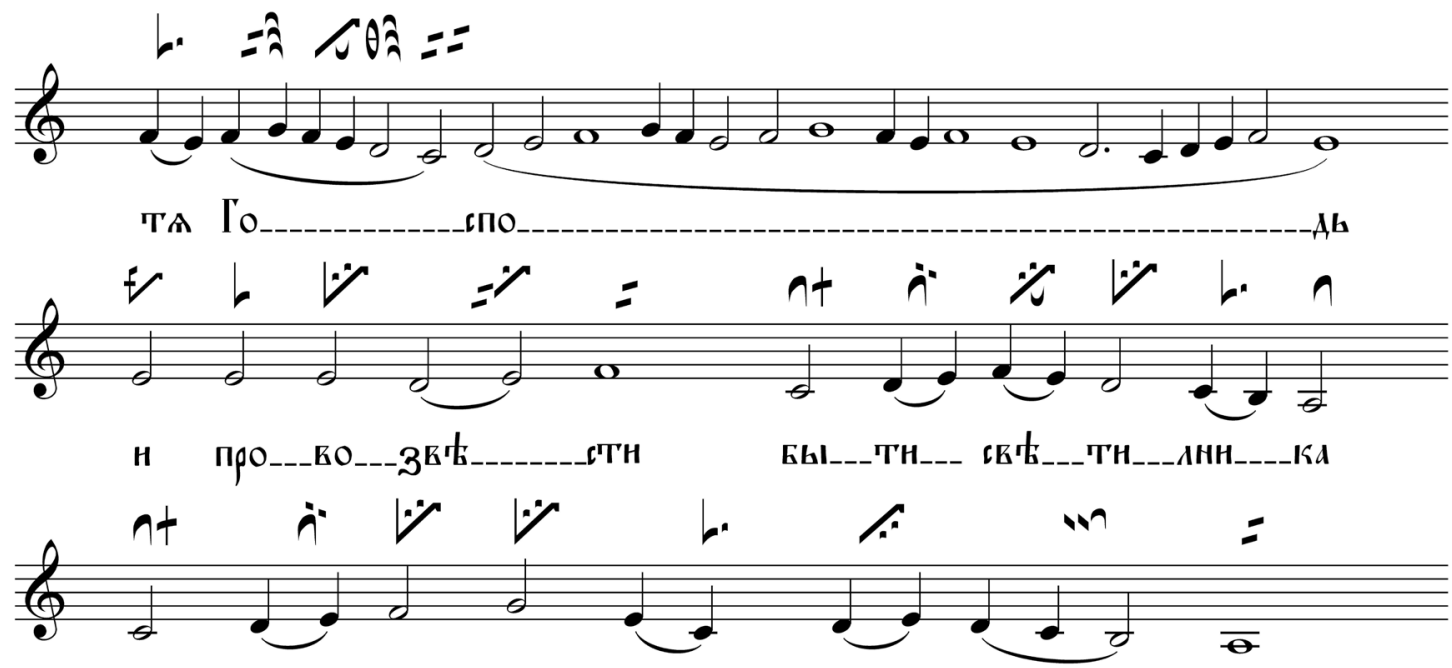
H OY

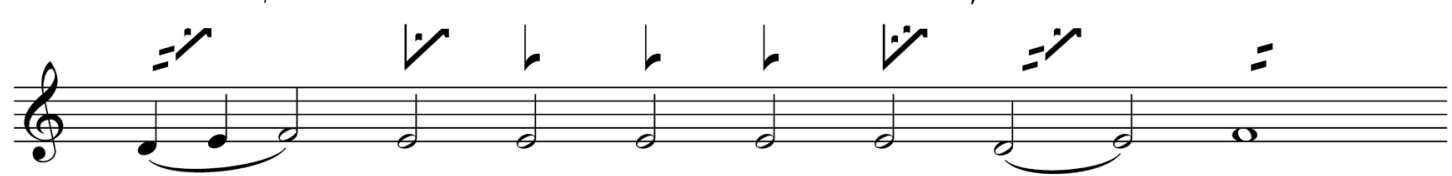

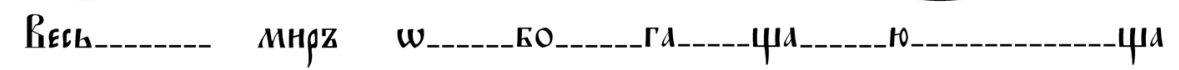
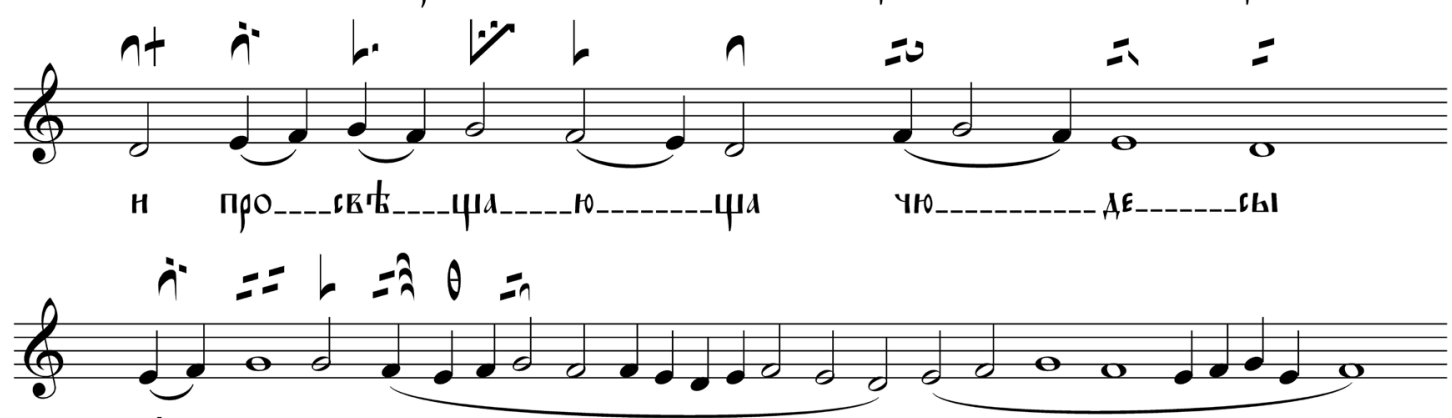

T'心MZ BO__חH_--E_-_MZ TH
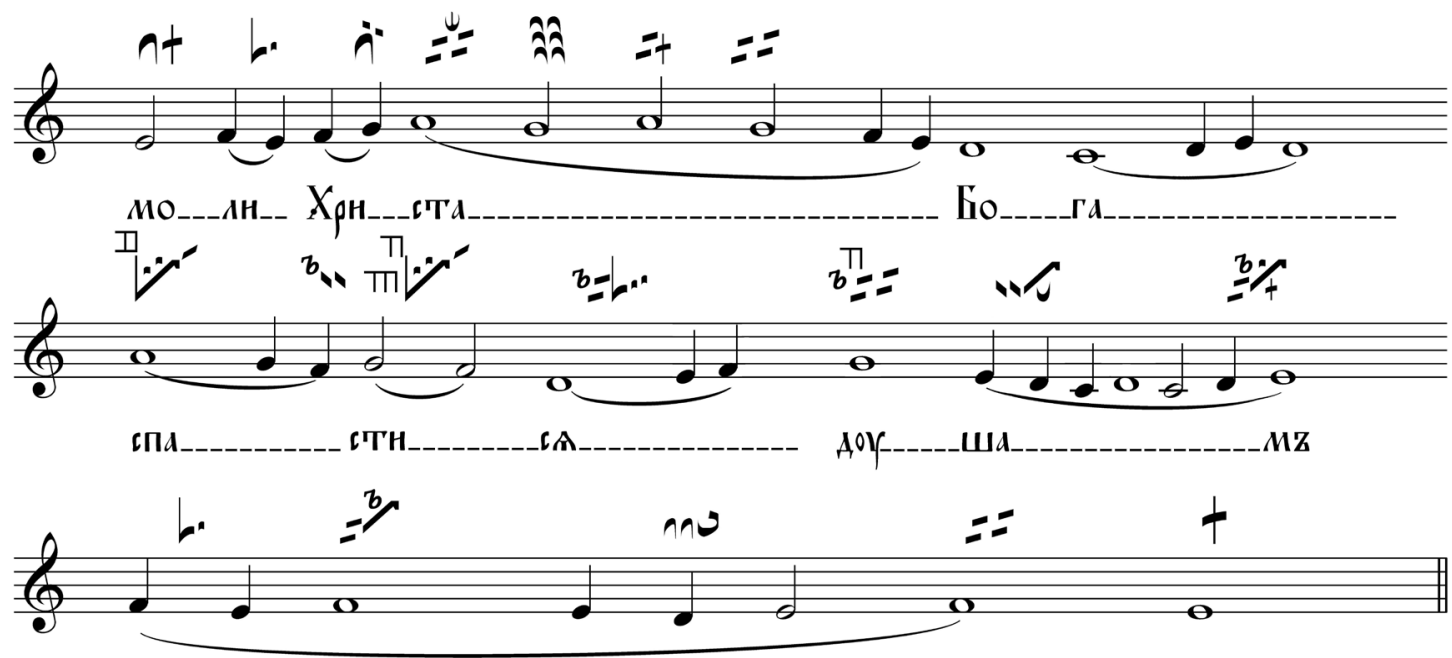

HA

UHMZ. 


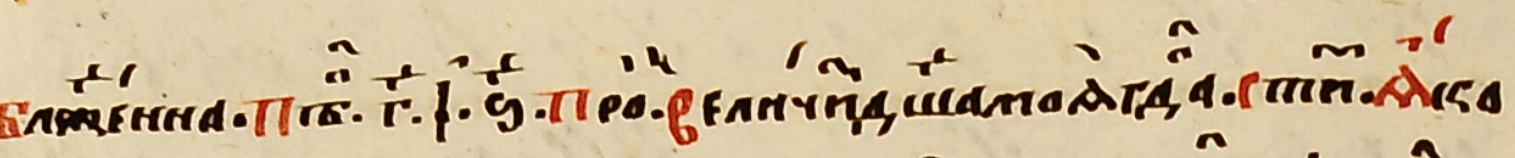

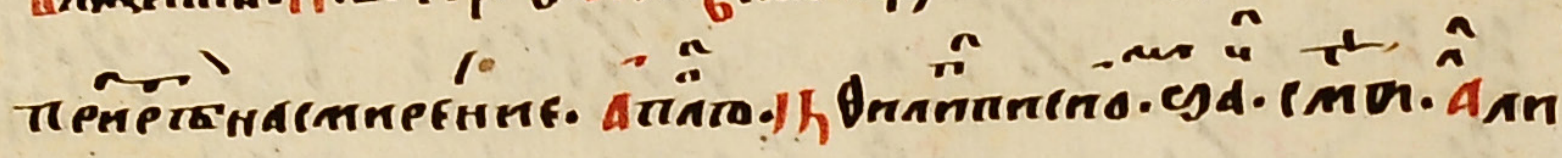

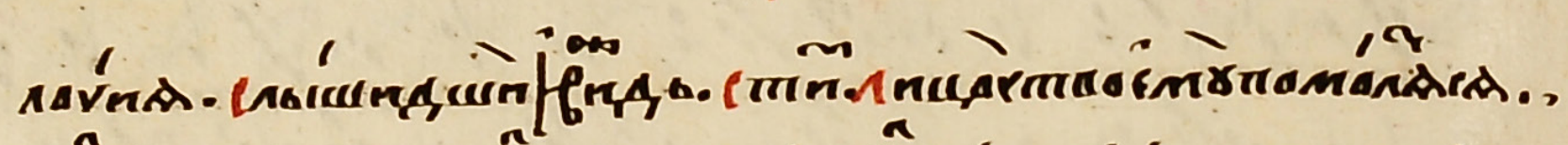

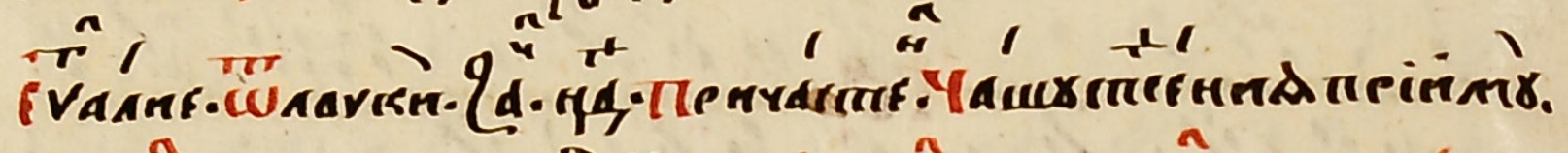

$A_{10}$

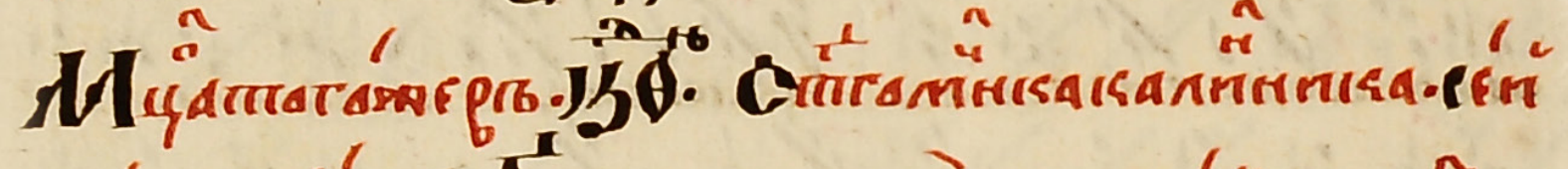

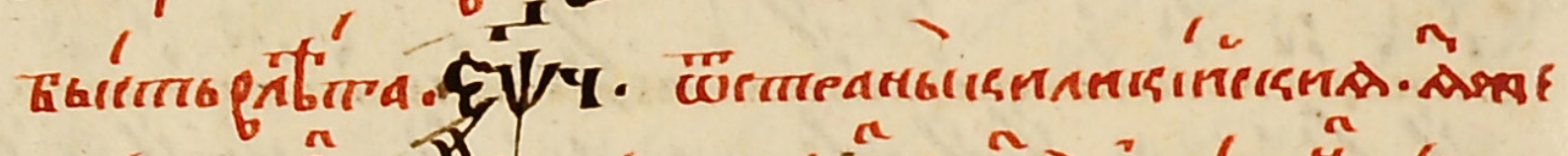

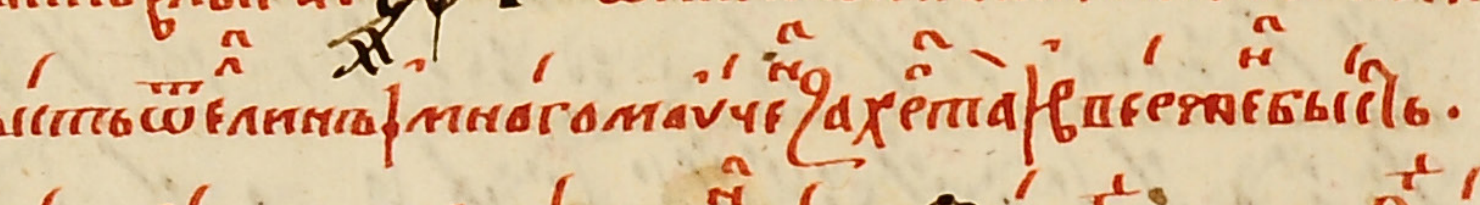

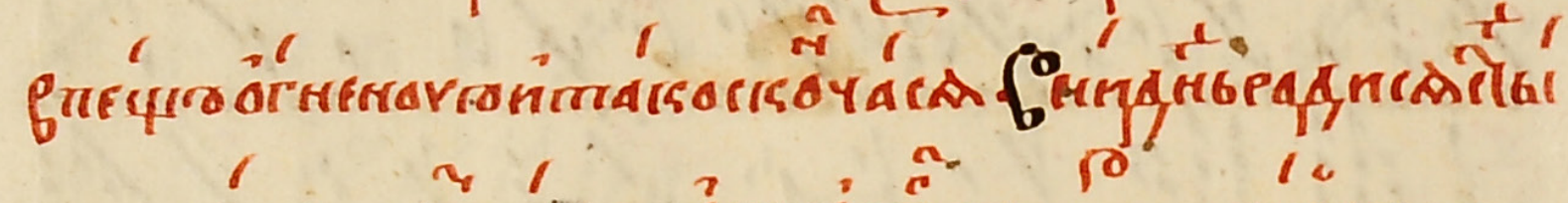

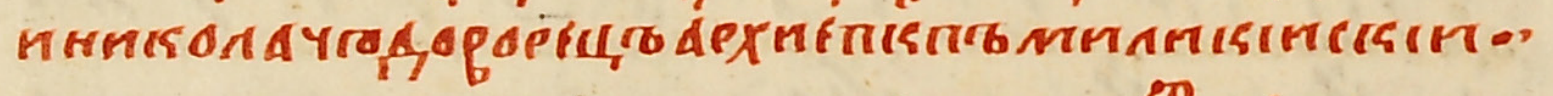

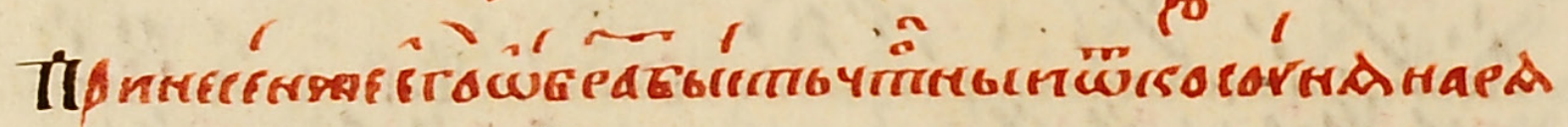

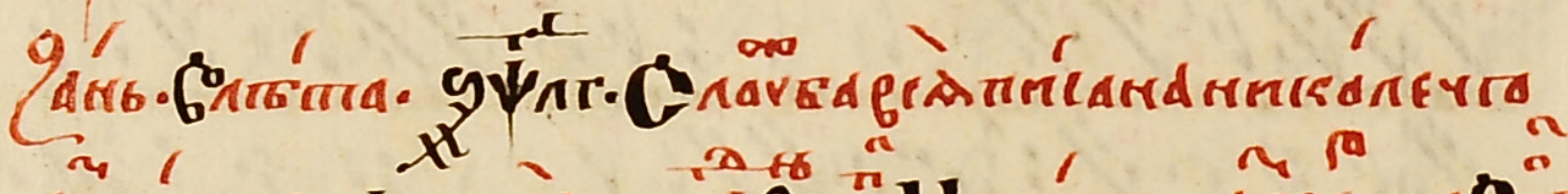

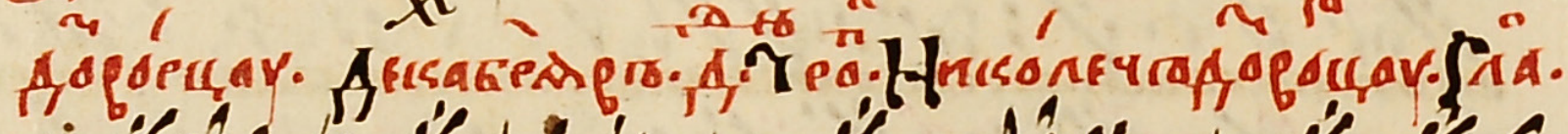

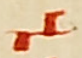

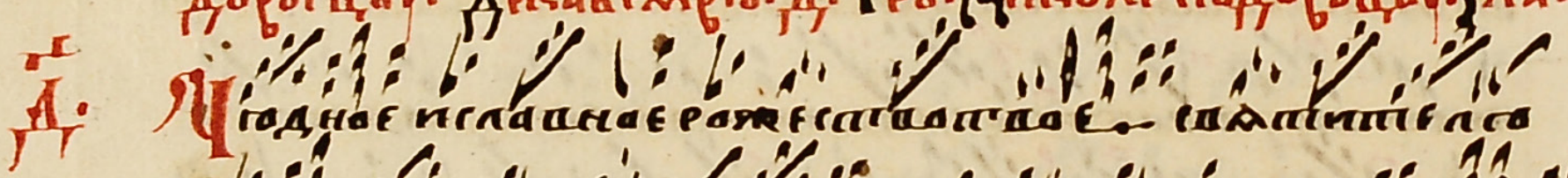
bo ấ

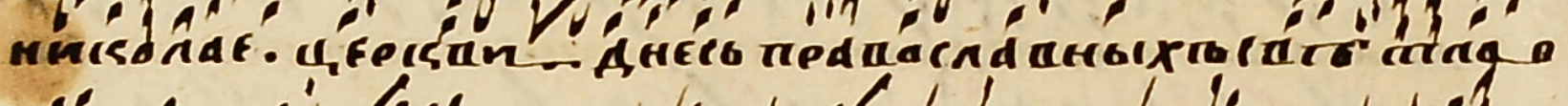

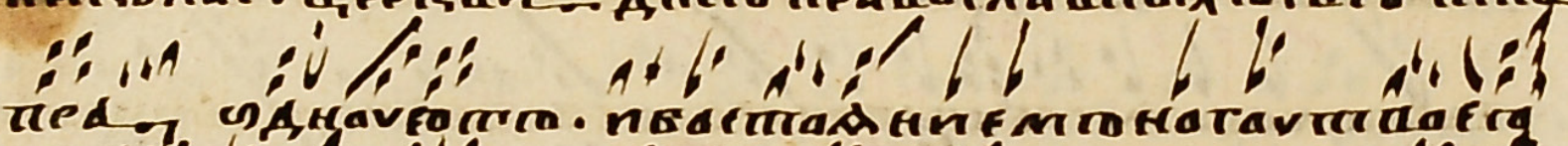

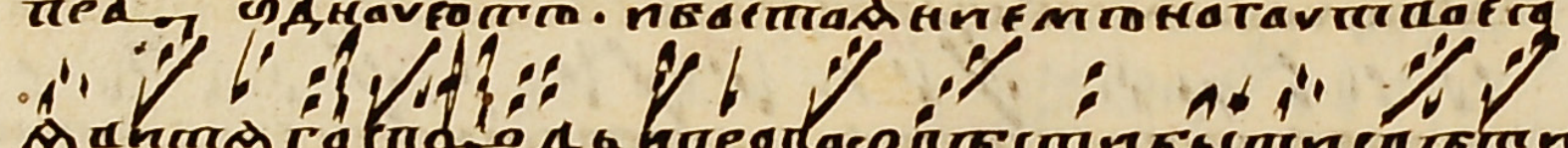

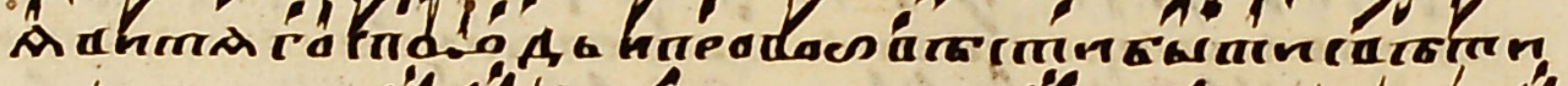

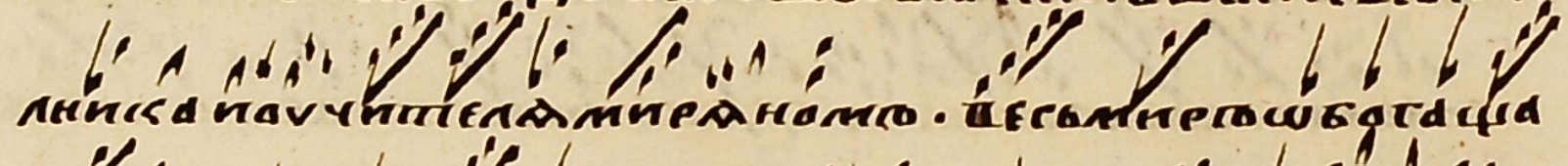

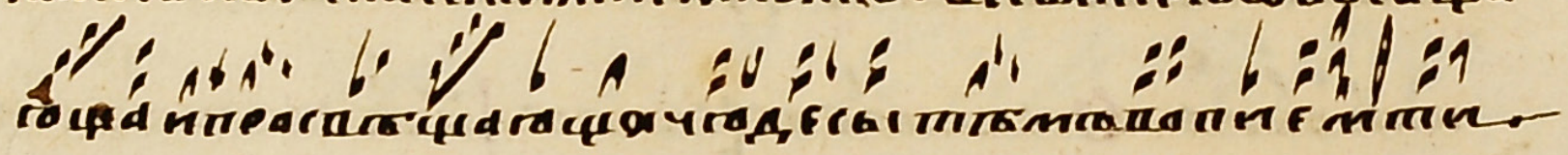




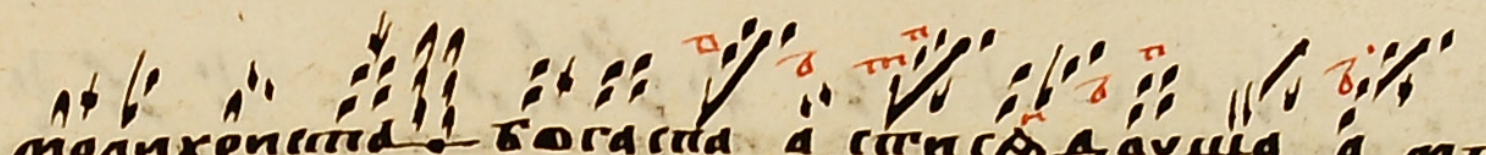

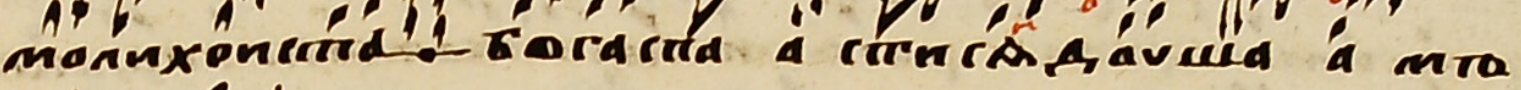

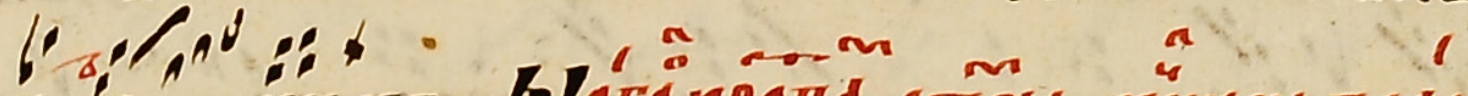

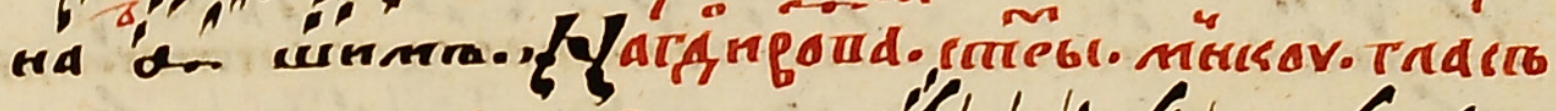

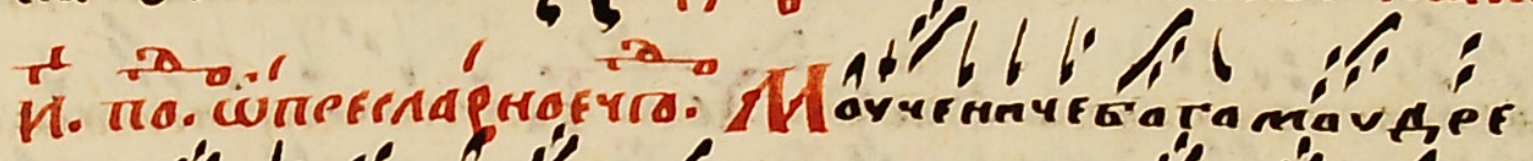

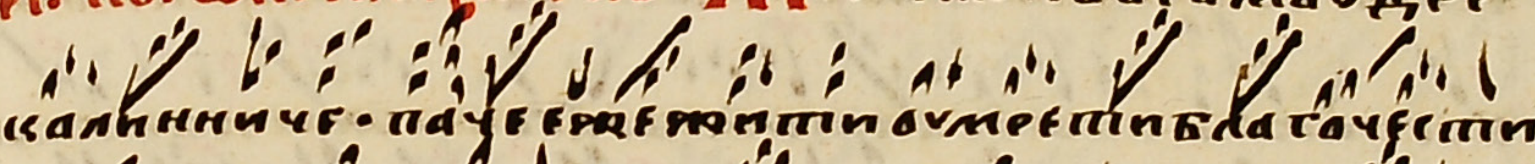

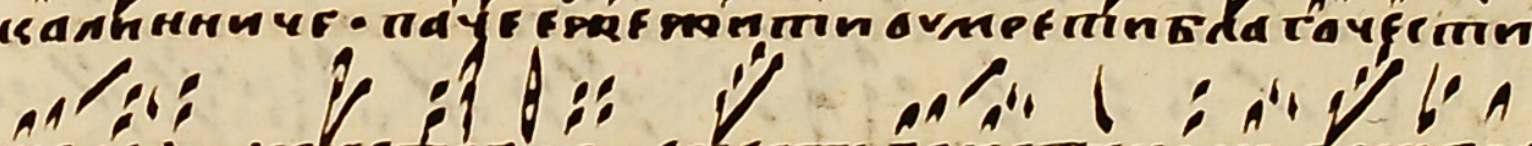

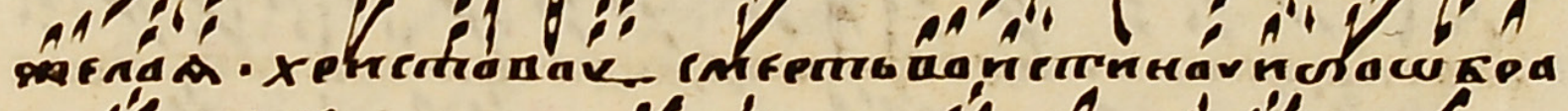
iो

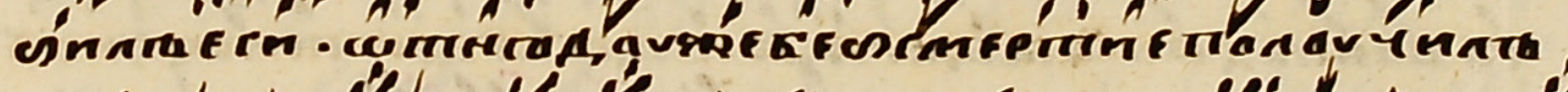

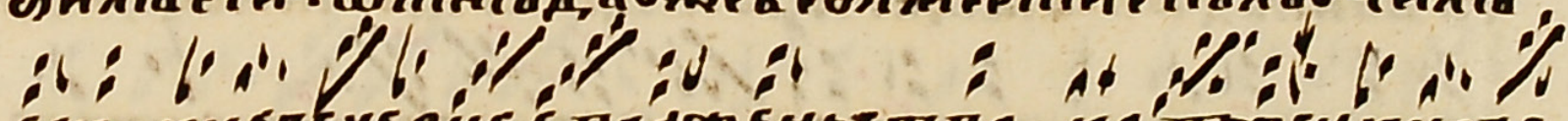

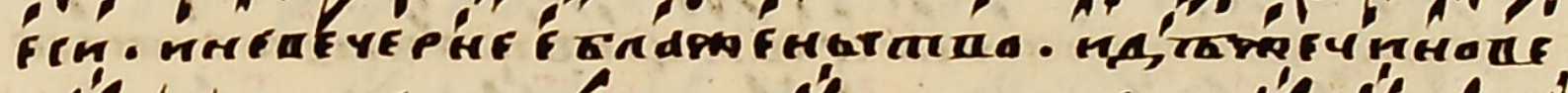

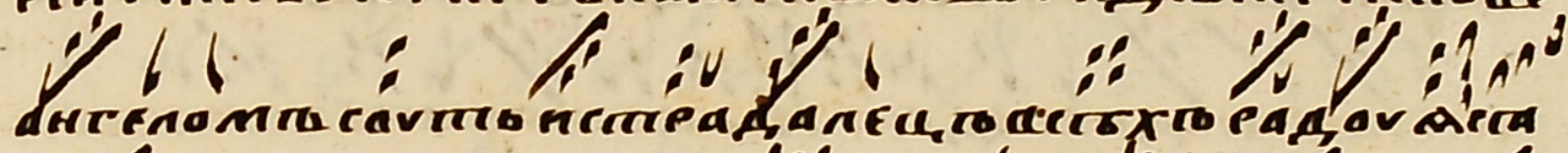

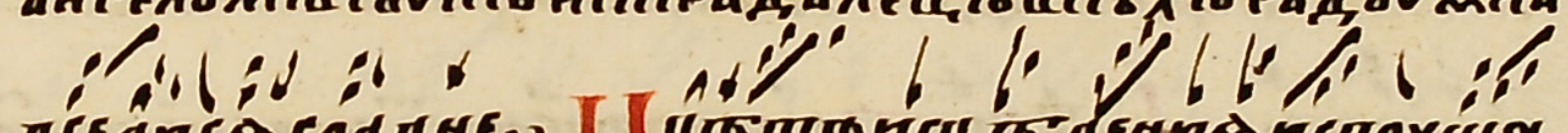

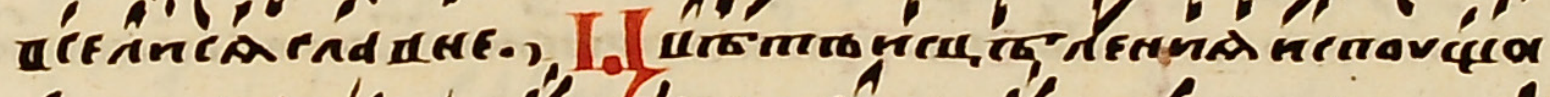

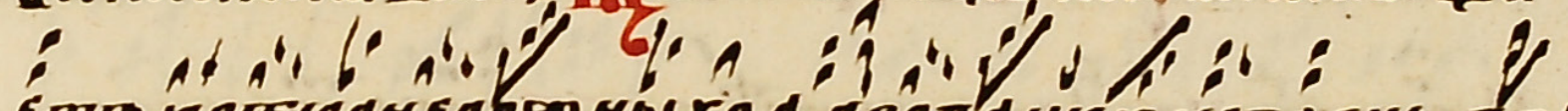

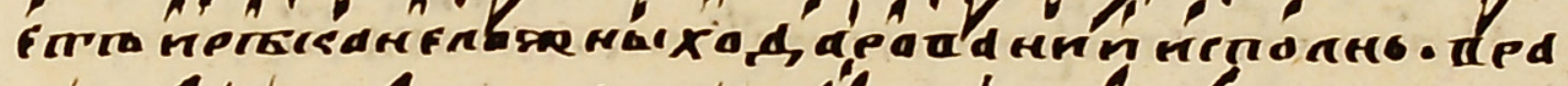

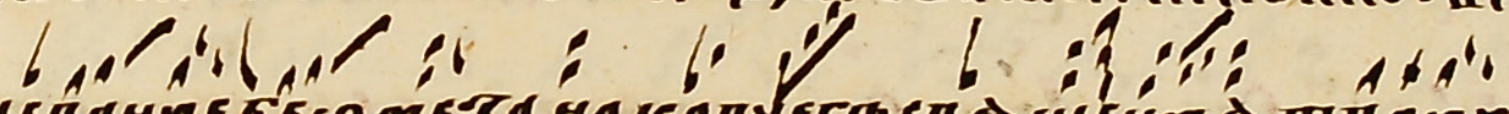

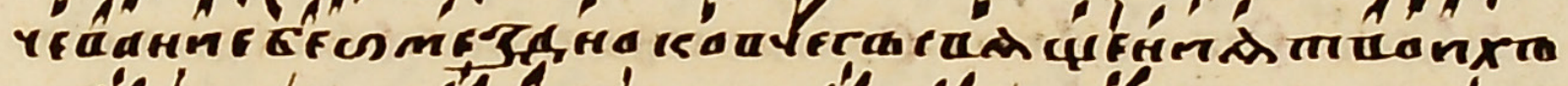

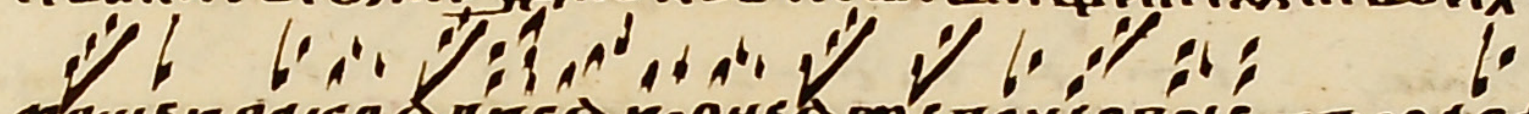

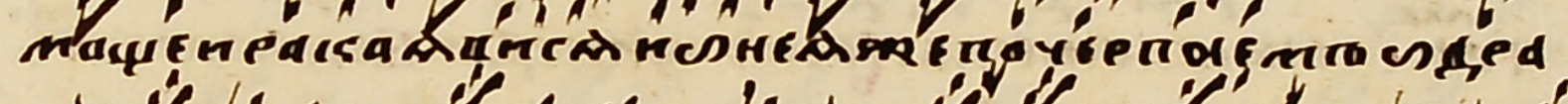

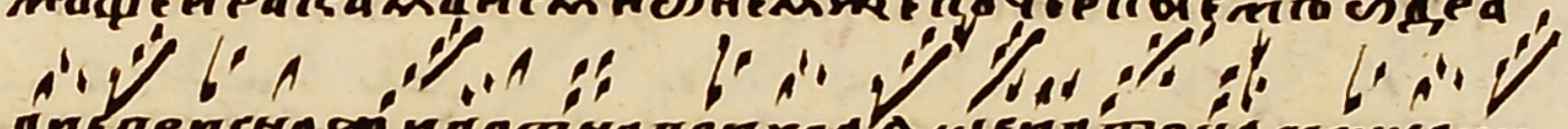

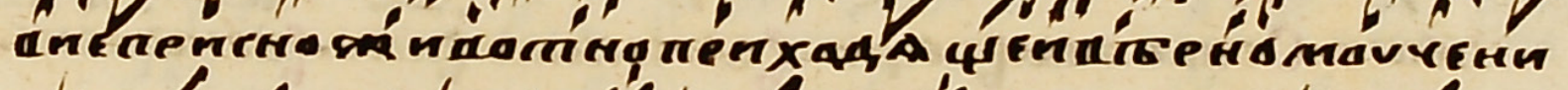

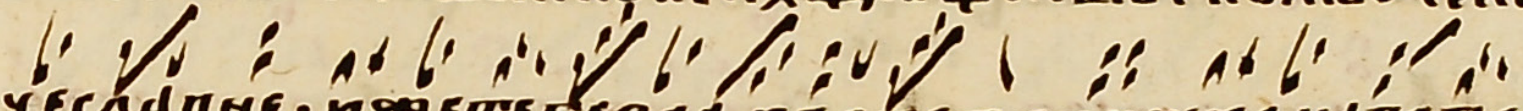

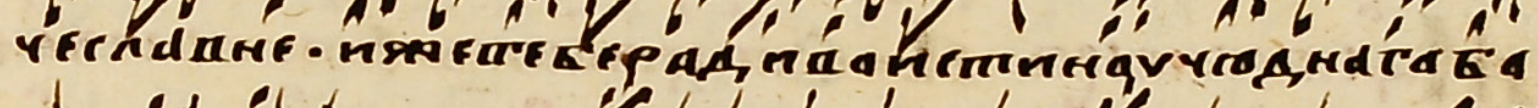
lof if.

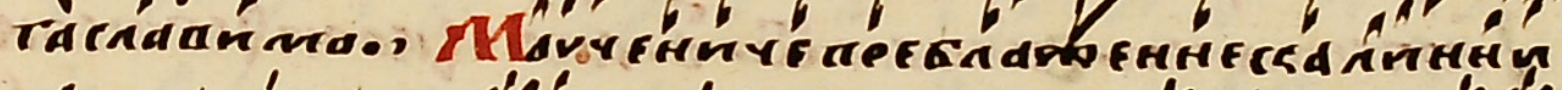

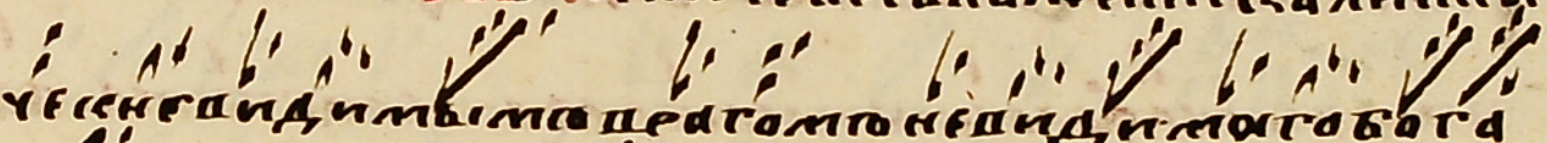
Nól'

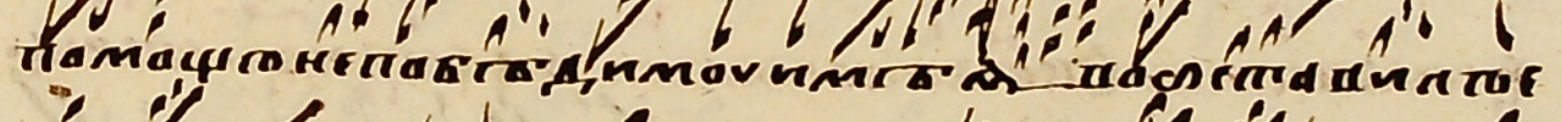

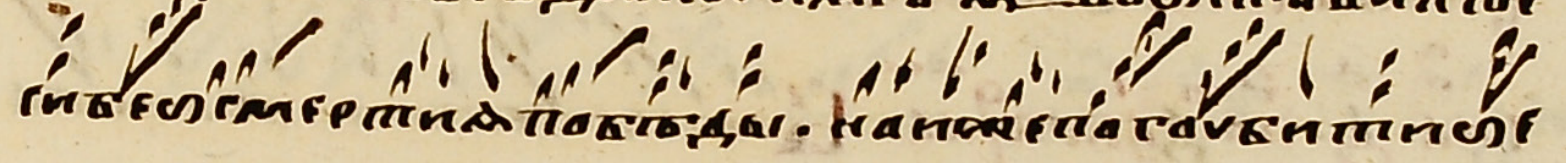


1. Chants Based on the Metaphrastovo Hagiography of St. Nicholas

The first group includes the troparion tone 4 "Taino derznovenne upodobilsya yesi..." and the kontakion tone 2 "V mireh rojeisya svyatii Nikolaye...". These chants are most often found in manuscripts. They are written out not only separately but also as part of services for the Nativity of St. Nicholas (the troparion is present in four of the five lists of a church service) ${ }^{19}$. The kontakion " $V$ mireh rojeisya..." was included in the printed editions of the $20^{\text {th }}$ century.

We compared the troparion "Taino derznovenne upodobilsya yesi..." with the corresponding chants on the Feast day of the Transfer of the Relics of St. Nicholas (May 9/22) ${ }^{20}$. It should be reminded that this Russian date was included in the church calendar shortly after the event of 1087 itself and fell right into line with the Greek remembrance day of the Repose of St. Nicholas (December 6/19). The comparison showed that the text of the Nativity troparion is also found in the hymnography on the Transfer of the Relics. The time of writing the troparion in the context of this holiday is limited to the $16^{\text {th }}$ century ${ }^{21}$. Since the beginning of the $17^{\text {th }}$

19. RSL. F. 98, No. 903, 1657, A Collection of Hagiographies and Services, f. 368-368; F. 299, No. 484.1, 1723, Collection of Hagiographies, Miracles of St. Nicholas and Services to him (of Russian origin), f. 215; F. 37, No. 438, $19^{\text {th }}$ century, Collection of services, mainly to Russian saints, fol. 467 about; F. 98, No. $1510,19^{\text {th }}$ century, Trefoloy March-August, $f$. 145. The first two of the listed sources are indicated in the book: Krutova M.S. Same work. The text of the church service according to these lists has been published (in modern spelling): S.Cherkasova Russian Church Services to the Nativity of St. Nicholas...

20. The phrase «Taino derznoveniye upodobilsya...» is given according to the list of the RSL, F. 98, No. 209, early $17^{\text {th }}$ century (1606), Church Charter, f. 502 (it is the earliest in a series of sources for the recording of the troparion), the text is also presented in the list F. 98, No. 903, 1657, Collection of Hagiographies and Services, f. 368-368; RSL, F. 98, No. 1510, $19^{\text {th }}$ century, Trefoloy March-August, f. 146-146.

In the manuscripts, there are other versions of reading: "Tainoderznovenne upodobilsya..." - RSL, F. 299, No. 484.1, 1723, Collection of Hagiographies, Miracles of St. Nicholas and Services to Him (of Russian origin), f. 215; "Derznovenne upodobilsya..." - RSL, F. 37, No. 438, 19 ${ }^{\text {th }}$ century, Collection of Church Services Mainly to Russian Saints, f. 466.

21. In the singing tradition of the Feast of the Transfer of the Relics, this troparion is better known in the following version: «llinu oupodobisya derznoveniyu mudre...». (The troparion "Ilinu oupodobisya" is tone 2, "Tayno derznovenne oupodobisya" - tone 4) In this case, the change of tone indicates a change in the content of the text and, in fact, the appearance of a new troparion. For more details see: Pavlova (Cherkasova) S.A. Content of Hymnographic Texts as a Basis for their Cantatory Interpretation // Scholarly notes of Russian Gnesins' Academy of Music / edited by I.S.Stogniy. Moscow. 2020. No. 3 (34). Pp. 92-106. century, it has been written out among the chants of the Nativity of St. Nicholas.

Let us cite the text of the troparion according to the earliest list discovered by us F. 98 , No. 209, $17^{\text {th }}$ century (before 1606) Charter: "Tainoderznoveniye oupodobilsya yesi mudre. Tsarya bo oblichil yesi angelom dvokrati. Izbavi tri mouji ot smerti.Tem po oyspenii tvoyem siyayeshi chudesi. Otche nash svyatiteliyu Nikolaye. Moli Hrista Boga spastisya dusham nashim".

The content of the troparion "Taino derznovenne upodobilsya yesi..." is associated with the Greek tradition of reverence of St. Nicholas, namely, with the glorification of the saint in connection with the miracle of the salvation of three voevodes. We have already written about it so we will only repeat the most important information here ${ }^{22}$. The act of the stratilates (a miracle has such a name in the Greek tradition) is the oldest recorded miracle of St. Nicholas. It served as the basis for the saint's hagiography and as the main subject of song creation. Moreover, a dogmatic interpretation of the miracle developed in Greek hymnography. In the voevodes' salvation from death, imprisoned by the slander of envious people, the song-makers glorified the salutary act of Christ, His Divine Economy ${ }^{23}$.

The act of the stratilates presents St. Nicholas as the savior of the soldiers who turned to him and as the guardian of the Equal-to-the-Apostles Tsar Constantine, who mistakenly punished his faithful servants. In the tsar's dream, St. Nicholas appeared twice with instruction, expecting obedience from him (salvation is accomplished instantly in another similar miracle from the hagiography of the saint - about the deliverance of three men from beheading by the sword). The motive of the saint's intercession and patronage of the legitimate princely power in the Russian tradition falls on fruitful spiritual soil ${ }^{24}$. In the feast of

22. Cherkasova S.A. Russian Church Services to the Nativity of St. Nicholas.

23. Cherkasov S. A. Hymnograhpy to Saint Nicolas: to the Issue of the Chanting System by the Principles of Podobnys // Saint Nicolas in Literary Texts and Iconography / Composed and edited by G.S. Klokova, M.S Krutova. Moscow: Orthodox Svyato-Tikhonovsky Humanitarian University, 2006 Moscow: Nauka Publishing house. Pp. 126-149.

24. There are historical grounds for this: the icon of «Nikola the Wet» «may have been among the first Byzantine gifts to the newly baptized Russian prince Vladimir» («The icon could have been brought to Kiev among the first sacred relics both from Constantinople as part of the dowry of Princess Anna, the wife of Vladimir $<\ldots>$, and from Korsun <...>» See: N.Vereshchagina. The Miraculous Image of St. Nicholas the Wet in the Eastern Slavic Cultural Tradition // The Rule of Faith and the Image of Meekness... The Image of St. Nicholas, Archbishop of Mirlikia, in Byzantine and Slavic Hagiography, Hymnography and Iconography / ed. A.Bugaevsky. Moscow, 2004. P. 408); the image of «Nikola 
the Transfer of the relics, in the stichera of the Nativity of St. Nicholas, especially in chants to the miraculous icons of the Saint, the theme develops persistently and masterfully. In addition to particular attention to the miracle of the salvation of the three voevodes and the appearance in a dream to Constantine the Tsar, St. Nicholas's talent is glorified in a generalized way in the Russian spiritual tradition: "knyazem okormitel...".

Kontakion tone 2 " $V$ mireh rojeisya svyatii Nikolaye..." is modeled after the kontakion tone 3 "V mireh svyate svyatitel yavilsya yesi..." on the feast of the Repose of St. Nicholas (December 6/19). Let us recall that the Russian Church inherited the Feast of the Repose from the Greek. Observing the Greek tradition, the hymnographer masterfully renewed it, expanding the text towards the Nativity ${ }^{25}$.

Attention is drawn here to two versions of the Nativity kontakion. The first one is presented in the manuscripts of the first half of the $17^{\text {th }}$ century. The second one - from the second half of the $17^{\text {th }}$ century up to the modern printed Menaion ${ }^{26}$. Let us compare the editions of the texts:

\section{First edition}

Kontakion tone 2

RSL. F. 199, No. 118, 1615, Church calendar

$\checkmark$ Mireh rojeisya, svyatii Nikolaye ot blagorodnago korene bogolyubimago ottsa Feofana. Iz lojesn bogoliybimuia ${ }^{27}$ materi Noni.

\section{Prorazumel yesi put spaseniya}

Ispolnilsya bojestvennif chudes biv svyatitel prepodobnii Nikolaye.

I prechuden uchenikom yavlsya Bojestvenniaia blagodati.

Lipensky» healed Prince Mstislav Vsevolodovich; «Nikola Zaraisky» appeared opening the gates of the Kingdom of Heaven to the family of Feodor Igorevich, Prince of the city of Krasny (Zarazsk); image of St. Nicholas «ugresha serdtse» of St. Dimitri Ivanovich (Donskoy); the image of «Nikola Velikoretsky» strengthened John Vasilyevich VI in the Kazan campaign, etc.

25. Pavlova (Cherkasova) S. A. Content of Hymnographic Texts...

26. In the printed Menaion of 1978-1989, the kontakion «V Mireh rojdesya...» was written out with the indication: tone 2, podobenIn V Mireh svyate. See: Service Menaion. July ... P. 297. In the handwritten tradition, it is different. The tone designation is different. Different sources may indicate the $2^{\text {nd }}$ or $3^{\text {rd }}$ tone. In the $17-18^{\text {th }}$ centuries, the kontakion "V Mireh rojdesya....» was written out without indicating podoben. The designation of podeben appears in the manuscripts of the $19^{\text {th }}$ century.

27. «...bogonravniya utrobi...» (RSL. F. 98, No. 903, 1657; RSL F. 299 No. 484.1, 1723).

\section{Second edition}

Kontakion tone 2. Similar to: $V$ Mireh svyate. Menaion, 2002.

$\checkmark$ Mireh rojdesya, svyatii Nikolaye, ot blagorodna korene

lako blagoplodna vetv prozyabl yesi

Ispoln bo biv Bojestvennih darov, iako solntse zaryami, ves mir chudesi presvetil yesi, sego radi proslavlyaem tya, yajo uchenika i tainnika Bojia blagodati.

The theme of salvation and miracles is in the center of the chant of the first edition's chant: "Prorazumel yesi put spaseniya ispolnilsya bojestvennih chudes". It continues with the Nativity kontakion from prosomoion, kontakion to the Presentation of St. Nicholas. In the prosomoion, the corresponding line of the text reads as follows: "spasl yesi nepovinniya ot smerti sego radi osvyatisya..."; in this line, two miracles, that follow one after the other in the hagiography of the saint, about the salvation of three men from beheading by the sword and the salvation of three voevodes from prison are presented in a generalized way: "spasl yesi nepovinnyaya ot smerti...".

In the second edition of the Nativity kontakion, the chain of meaning, which starts from the prosomoion, is interrupted. Instead of a line from prosomoion: "...spasl yesi nepovinniya ot smerti..." (meaning in the first edition of the text as "...prorazumel yesi put spasenya..."), the second edition reads: "...yako blagoplodnaya vetv prozyabl esi...". What happened? The editor replaced the glorification of St. Nicholas's specific acts with a common phrase, "blagoplodnoi vetvi...", in hymnography. It should be reminded that the reading of these miracles in Greek hymnography (followed by Russian hymnography) implied a dogmatic component.

The glorification of St. Nicholas's saving acts, his gift of miracles, is put in a certain context. At the beginning of the chant, it is said about the parents, at the end - about the divine grace. In the second edition of the kontakion, a leisurely story about the parents of St. Nicholas is shortened. A generalization, "...ot blagorodnago korene..." [of honorable descent], remains there. The content does not change in general; however, in particular, it is depersonalized. The chanting of specific names 
and deeds give time for reflection, and there is something to think about.

What were the parents of St. Nicholas if "put spaseniya" [path of salvation] the future Saint "prorazumel" [learnt] "...ot blagorodnogo koreni bogoliubimogo otsa Feofana, iz lojesn bogoliubimoi materi Noni... " [from God-beloved Father Theophan, from God-loved mother Nona]? The saint's hagiography says about the parents: "... nekto blagoroden muj <...> emu je imya Feofan $<. . .>$ Supruga je emu Nona. Siye je blagoslovennoye suprujestvo so vsyakim dobronraviyem blagochestiya derjashesya $i$ vo pravovernoy vere, iaje vo Hrista Boga, prisno hvalyashesya..." ${ }^{28}$ [a noble husband $\langle\ldots\rangle$ his name is Theophan $\langle\ldots\rangle$. His wife is Nona. This is a blessed marriage with all the good-naturedness, keeping righteousness, in the orthodox faith in Christ.].

Important details show that the birth of such an ascetic like St. Nicholas is deeply connected with the feat of the life of his parents, their "dobronraviyem" [good nature], "blagochestiya derjashesya" [keeping righteousness], " $i$ vo pravovernoy vere, iaje vo Hrista Boga" [orthodox faith in Christ]. This is what is sung in the kontakion of the first edition.

Thus, in the content of the troparion tone 4 "Taino derznoveniye upodobilsya yesi mudre..." and kontakion tone 2 "V Mireh rojdsya svyate Nikolaye...", hymnographers based on the Greek tradition of hymning St. Nicholas, drawn from the Metaphrastov hagiography. This was directly manifested in the glorification of the miracle of the salvation of the voevodes and in the hymning of St. Nicholas's parents - Theophan and Nona. In terms of the artistic word and form of chants, the authors were guided by the corresponding texts of two famous holidays of St. Nicholas: the Russian memory of the Transfer of the relics and the Greek memory of the Repose of the saint ${ }^{29}$.

\section{Chants Based on the "Inoyie" [other]} Hagiography of St. Nicholas

28. Krutova M.S. Same work. Pp. 10-11.

29. Let us also note the intersections in the content of the troparion and kontakion with the hymnography of the feast of the Nativity of Christ. In the kontakion, it is associated with singing podoben, meaning that the texts through the kontakion of the holiday for the Bringing of the relics of St. Nicholas go back to the kontakion of the Nativity of Christ «Deva Dnes». The troparion repeats the memorable, vivid turn of speech at the beginning of the troparion of the Nativity of Christ «...Tayno rodilsya yesi $v$ vertepe».
This group of texts includes the largest number of chants: troparion tone 2 "Tserkvi tvoya Gospodi svetlo prazdnuiut..." [Your churches, Lord, are celebrating]; troparion tone 4 "Chudnoye $i$ slavnoye rojdestvo tvoye..." [wonderful and glorious is your birth]; troparion tone 2 "Dnes vozsya nam yako solntse torjestvo tvoye..."; troparion tone 4 "Otechestvo tvoye i rojenie i vospitaniye..."; kontakion tone 3 "Vzide yako zvezda ot vostoka i do zapada tvoe rojdenie i vospitanie...".

Like the chants presented in the previous group, troparion tone 4 "Chudnoye i slavnoye rojdestvo tvoye..." is often found in handwritten sources. Twice it is written in the Nativity services of St. Nicholas ${ }^{30}$.

In the process of research, it became clear that this troparion is the edition of the "drugogo troparya" [other troparion] for the Nativity of St. Nicholas, tone 2, "Tserkvi tvoya Gospodi svetlo prazdnuiut..." ${ }^{31}$. The latter is represented as the only list in the manuscript of the early $17^{\text {th }}$ century: RSL, F. 199, No. 118, 1615, Church calendar. The revision was made before 1648-58. The most initial source containing the troparion "Chudnoye i slavnoye rojdestvo tvoye..." dates from these same years. This manuscript is from the collection of D.Razumovsky F. 379 No. 66, Menaion for June-August. By the type of the book, it is the so-called "Diachye oko" [Book of Sticheron], "a sample sticheron which existed in the Studion era and has been reviving since the middle of the $16^{\text {th }}$ century" ${ }^{32}$. D.Razumovsky specifies the time of the creation of the manuscript: "It was written under Tsar Alexei Mikhailovich <...> and Patriarch Joseph $<\ldots>$ not earlier than 1648 and not later than $1658^{\prime \prime 3}$. It is in this list that the notated record of the troparion is presented which is published in this article.

Let us compare the texts of the troparia:

30. BAN, Vyatka Collection, No. 66 , early $18^{\text {th }}$ century, Collection of Hagiographies and Church Services to St. Nicholas; RSL, F. 98, No. 1510,19 ${ }^{\text {th }}$ century, Trefoloy March-August, f. 83, f.146.

31. In turn, the troparion "Chyudnoye i slavnoye Rozhdestvo tvoye...» probably served as the basis for "another troparion», tone 2 "Dnes' vozsiya nam yako solntse torzhestvo tvoye..." (BAN Vyatka Collection, No. 66, 18 ${ }^{\text {th }}$ century). The latter troparion is not considered in this article.

32. Ramazanova N.V. Moscow Tsardom in the Art of Church Singing of the $16-17^{\text {th }}$ Centuries. St.Petersburg: Dmitry Bulanin Publishing House. 2004. P. 31.

33. See: The Description of the Collection of Handwritten Books by D.Razumovsky. Fund No. 379. Moscow: RSL, 1958. Pp. 8586. 
Troparion tone 2

RSL F. 199, No. 118, 1615,

Church calendar

Tserkvi Tvoya Gospodi

svetlo prazdnuyem

chestnago tvoyego rozhdestva

otche Nikolaye.

yegda khoshchet tya baba omyti

stoyaniyem tvoyeya nogi

proslavi tebya.

svetilnika i uchitelya miru.

yako svoya roditeli udivil yesi rozhestvom svoim otche Nikolaye.

moli Khrista Boga

spastisya dusham nashim.

Troparion tone 4 (edition)

RSL F. 379, No. 66, 1648-50,

Menaion June-August, on kryuki

Chyudnoye i slavnoye rozhestvo tvoye

svyatitelyu Nikolaye.

tserkvi dnes Pravoslavnykh

svetlo prazdnuyut.

ibo stoyaniyem nogu tvoyeyu

yavi tya Gospod. i provozvesti byti svetilnika $i$ uchitelya miryanom.

ves mir obogashchayushcha

i prosveshchayushcha chudesy

tem vopiyem $t i$

moli Khrista Boga

spastisya dusham nashim.

The first lines indicate a festive event. In the troparion "Chyudnoye i slavnoye rozhestvo tvoye", it is specified that the holiday is celebrated by "tserkvi $<\ldots>$ Pravoslavnykh" [Churches <...> Orthodox].

In the middle lines, the miracle of standing on legs, performed by the infant at birth, is celebrated. In the "other" hagiography of St. Nicholas, it is said: "...yegda $j$ bo roditisya, kuplemu yemu $v$ nochvakh ${ }^{34}$,

34. "Nochvi - Ukrainian: trough, tub; Russian Church Slavic: нъщьвы <...> «. Fasmer M. Etymological
Bozhiyeyu siloyu sta na nogu svoyeyu prost do dvoyu chasu..." ${ }^{35}$. In the troparion "Tserkvi Tvoya Gospodi svetlo prazdnuyut...", the hymnographer clarifies that the baby was washed by "baba" [midwife]: "...yegda khoshchet tya baba omyti stoyaniyem tvoyeya nogi proslavi tebya..." ${ }^{36}$. Perhaps, such features of the text indicate its antiquity. In the version "Chyudnoye $i$ slavnoye rozhestvo tvoye...", the line is shortened and edited stylistically: "...ibo stoyaniyem nogu tvoyeyu...".

The miracle performed in infancy is sung as a prophecy of the future talents of the saint: "... rozhestvo tvoye $\langle\ldots\rangle$ tserkvi dnes $\langle\ldots\rangle$ svetlo prazdnuyut. ibo stoyaniyem nogu tvoyeyu yavi tya Gospod. i provozvesti byti svetilnika i uchitelya miryanom...". Both editions agree on this.

In the final lines of the first edition of the kontakion, St. Nicholas's parents are mentioned: "... roditeley udivil yesi rozhestvom svoim..." [surprised your parents with your birth]. In the second edition, there is no talk of them, only about the "worldwide" glory of the saint: "...ves mir obogashchayushcha $i$ prosveshchayushcha chudesy..." [the world is enriched and enlightened with the miracles]. Such a "cadence" on the theme of world fame, perhaps, allowed the songwriter to change the tone of the troparion from the $2^{\text {nd }}$ (in the first edition) to the "all-celebratory" $4^{\text {th }}$ (in the second edition) ${ }^{37}$.

Another troparion is built on the "other" hagiography materials, tone 2 "Otechestvo tvoye $i$ rozhdeniye $i$ vospitaniye..." [your Fatherland and birth and upbringing]. It is written together with the kontakion tone 3 "Vzyde zvezda ot vostoka $i$

Dictionary of the Russian Language: In 4 volumes / Transl. From German and notes: O.Trubacheva. $3^{\text {rd }}$ ed. Moscow: Terra Publishing House. 1996. V. 3. P. 601.

"Netsva: - Nikolaya Chudotvor'tsa pomyti yego khotyashchi, baba polozhi i v netsvakh. Prol. 1432, f. 132 «. Sreznevsky I.I. Materials for the Dictionary of the Ancient Russian Language Based on Written Records. St.Petersburg: Edition of the Department of Russian language and literature of the Imperial Academy of Science. 1890-1906. V. 2: L - P. 1895-1902. 1802. P. 440.

35. Krutova M.S. Same work. P. 95

36. The word «baba» is used in the meaning of «a midwife». Sreznevsky I. I. Same work. I, p. 31.

The parallels with the iconography of the Nativity of St. Nicholas, which implies the image of a «woman» (a midwife) who either holds the baby in her arms at the font («nochvi») or is next to him at the moment of the miraculous "standing on legs», are interesting... «Iconographic originals» repeat the songwriter word for word. For example, "yegda nachasha yego omyvati be nochvakh malo postoya" (RSL F.734, No. 52, 1698, f. 177) or "yegda stala yego mati omyvati v nogakh malo postoya" (RSL F. 579, No. $42,18^{\text {th }}$ century, f. $236 ;$ F. 178, No. $3474,2^{\text {nd }}$ half of the $18^{\text {th }}$ century, f. 181 , etc.). The word «mati» appears in the texts of the «Iconographic Originals» only in the $18^{\text {th }}$ century. 37. Nikolaev Boris, Archbishop. Same work. P. 94. 
do zapada rozhdeniye tvoye $i$ vospitaniye..." 38 [the star rises from East to West, your birth and your upbringing].

In compiling the troparion and kontakion, the hymnographer was guided by the texts of the same name (on the first line) of the feast of the Transfer of the relics of St. Nicholas (May 9/22). Arrangements were made by replacing individual words and expanding, adding new lines to the text. For example, instead of the "Mir Likiyskikh" and "grada Barskogo", as was the case in the chant for the Transfer of the relics, the compiler put on the poetic "map" the toponyms of the Nativity of St. Nicholas from the "other" hagiography: "...Tarsakilskiy grad..." (aka "Tarshish"), "...Kalasiskiy monastyr.." (aka "Zion"), etc. The repetition of toponyms suggests didactic orientation of the text.

The hymnographer chooses the miracle of "diligence in fasting" performed by St. Nicholas in infancy. This miracle unites all "types of hagiographies" and is written out in the St. Macarius Great Menaion Reader. In the troparion, it is sung: "...i ot maternikh sosets ne priimashe...". It is specified in the hagiography: "...v sredu bo i v pyatok yedinoyu [ot sosets] prichashchashesya mleku, i to zhe vo vremya vecherneye, yezhe po sovershenii Bozhestvennago pravila..." ${ }^{39}$. This amazing miracle shows St. Nicholas in Nativity as the same ascetic that he is in the Repose. Let us recall the troparion tone 4 "Pravilo very..." [the rule of faith] and an appeal to the Holy Hierarch "...vozderzhaniyu uchitel...".

The holiday theme is interestingly presented in this pair of chants: "...tvoye rozhdeniye $i$ vospitaniye..." [your birth and upbringing]. In the concluding lines of the kontakion, it is specified: "...otrok $v$ rozhdenii svoyem i vospitanii <...> prediven i milostiv" [the youth in his birth and upbringing $<\ldots>$ is delightful and merciful] The names of the educators are written in the troparion: in addition to the "roditeley" [parents], these are "uchitel i nastavnik Savvatiy" [teacher and mentor Savvaty] and "stroitel Nikola" [builder Nikola]. The rest of the hymnography emphasizes that St. Nicholas already "vo utrobe materney svyatitel'stva prozvaniye priim..." at the time of Nativity. In other words, his "vospitaniye" [upbringing] by the time of "rozhdeniya" [birth] had already been completed. This was the reason for the

38. For the publication of the texts of the troparion and kontakion, see: Pavlova (Cherkasova) S. A. Russian Hymnography to St. Nicholas... Pp. 49-63.

39. Krutova M.S. Same work. P. 11. amazement and glorification of St. Nicholas in his Nativity and, possibly, became the reason for the establishment of the holiday. We no longer see the glorification of "vospitaniya" [upbringing] in any hymn to the Saint.

Thus, the troparia and kontakia, written according to the "other" hagiography of St. Nicholas, glorify the miracles performed by "otrokom predivnym i milostivym" [delightful and merciful youth] in infancy. In them, hymnographers see the prophecies of the future talents of the Saint.

The hymns of the holiday for the Transfer of the relics of St. Nicholas serve as a guideline in the compilation of some texts.

\section{Chants in Praise of the Russian Glory of St. Nicholas}

This group consisted of two texts: troparion tone 4 "Preslavnomu rozhdestvu tvoyemu angel'stiy chinove..." and kontakion tone 3 "Yakozhe $v$ rozhdestve vozsiyal yesi Dukhom Presvyatym...". Both chants are known in the only list of the $17^{\text {th }}$ century (see the table of troparia and kontakia with an indication of the handwritten source at the beginning of the article).

The text of the troparion tone 4 "Preslavnomu rozhdestvu tvoyemu..." is as follows: "Preslavnomu rozhdestvu tvoyemu angel'stiy chinove nemolchno vospevayem ustny yako Gospod' khoshchet pokazati svetilnika i ugodnika svoyego Nikolu. zovem tebe prilezhno vse. Ukrepi nas i vrazhiyu silu i sovety uprazdni poganykh . na nas vostayushchikh bezbozhnykh vragov pogubi. Bozhestvennym . Khristovym poveleniyem".

A pure serene look. A world, in which we all "nemolchno vospevayem ustny" [sing without speaking] and "zovem prilezhno" [diligently call] St. Nicholas, is presented in the Christian coordinate system. "Longitude" is "...angelstiy chinove..." [an angelic rank] (to which St. Nicholas belongs). "Latitude" is "...na nas vostayushchiye bezbozhnyye vragi..." [godless enemies rising up against us]. The description of enemies is frightening. They are both "poganyye" [vile] and strong ("vrajya sila" [the power of the enemy]), and "vostayushchiye" [uprising] and "bezbozhnyye" [godless]. It can be seen that the troparion is a reflection of life, profoundly disturbing.

A simple conciliar thought. "Nicola" is not by himself but in the "angelic rank": "Preslavnomu rozhdestvu tvoyemu angel'stiy chinove nemolchno 
vospevayem ustny...". "Nikola" is not a "luminary" but "...yako Gospod' khoshchet pokazati svetilnika i ugodnika svoyego Nikolu . zovem tebe prilezhno vse... ". "Nikola" does not help alone but "...Bozhestvennym . Khristovym poveleniyem".

In one manuscript, "another troparion" tone 2 "Tserkvi Tvoya Gospodi svetlo prazdnuyut..." [Your churches, Lord, are celebrating] is written with the troparion "Preslavnomu rozhdestvu tvoyemu angel'stiy chinove...". Both texts probably represent the oldest layer of the Russian hymnography in praise of the Nativity of St. Nicholas.

"We know very little about the secrets of the Heavenly World, and it is not easy to convey it with earthly human images," writes Protopriest Boris (Nikolaev) in connection with the content of the chants tone 3, "That is why there are not many chants of this tone" ${ }^{40}$. Kontakion tone 3 "Yakozhe $v$ rozhdestve vozsiyal yesi Dukhom Presvyatym..." undoubtedly belongs to this group.

"Earthly human images" of St. Nicholas and his parents are revealed in chants in the "svetlostyakh budushchego veka" 41: "Yakozhe v rozhdestve vozsiyal yesi Dukhom Presvyatym ot Nonny i Feofana, angelom pokazasya zakonen, Khrista radi rodisya, Nikolaye, otrocha mlado slavnyy, angelom i prorokom spozhitel' byst' s nimi zhe Khrista Boga moli neprestanno o vsekh nas".

St. Nicholas is glorified as a "angelom i prorokom spozhitel". The song creator "tikho raduyetsya" [quietly rejoices] how the Miracle Worker from the very birth "zakonno" [lawfully] prays together with the orders of heaven.

Parents of St. Nicholas are glorified in a series of Divine names - Christ and the Holy Spirit: "...v rozhdestve vozsiyal yesi Dukhom Presvyatym ot Nonny $i$ Feofana, angelom pokazasya zakonen, Khrista radi rodisya....".

The hymnographer chooses the angelic image from the birth of the saint, in his infant miracles. The baby "Khrista radi rozhdennyy" [born for Christ's sake] surprises with an angelic life. The miracles themselves are not named in the chant, we know about them from the hagiography: "...Bozhiyeyu siloyu sta na nogu svoyeyu prost do dvoyu chasu..." 42 , "...v sredu bo i v pyatok yedinoyu [ot sosets] prichashchashesya mleku..." ${ }^{43}$. The hagiography is echoed by

40. Nikolaev Boris, Archbishop. Same work. P. 94.

41. Ibid. P. 94.

42. Krutova M.S. Same work. P. 95.

43. Ibid. P. 11 the praiseworthy hymnography: "Angela obrazom zemnago sushcha yestestvom..." (the beginning of the akathist to St. Nicholas), "Angelu blagovestitelyu upodobilsya ty yesi Nikolaye..." (from the akathist to Zaraisk icon), etc.

The prophetic image is formed partly due to the interpretation of infant miracles as indicators ("...pokaza tya Gospod..") of the future glory of the saint, partly due to the hymnography of other feasts of St. Nicholas: "...yako vtoryy Predtecha na zemli yavilsya yesi, svyate otche Nikolaye..." (Repose, May 6/19), "Iliinu podobisya derznoveniyu mudre..." (Transfer of the relics, May 9/22). This topic is essential for Russian hymnography. Having appeared in Russia long before Epiphany, St. Nicholas was one of the first prophets of Christianity in our Fatherland ${ }^{44}$. Since then, for over a thousand years "...Bozhestvennym. Khristovym poveleniyem" [By Divine. Christ's will] St. Nikolay warns, strengthens, protects "lyudi svoya" [his own people].

A short study about the holiday's primary chants, the troparia and kontakia, shows the rich tradition of reverence of the saint in his Nativity. The content of the chants assimilated the heritage of the Greek Church and, at the same time, reflects its own vibrant Christian culture. The hymnographic legacy of the feast of the Nativity of St. Nicholas is experiencing a revival these days. Everything is ready "...nemolchno vospevat' usty yako Gospod' khoshchet pokazati svetilnika i ugodnika svoyego Nikolu" [to praise as the Lord wants to show his luminary and saint Nichol...].

Publication: Troparion tone 4 "Chudnoye $i$ slavnoye rozhdestvo tvoye...".

Department of Manuscripts of the Russian State Library, Collection of D.Razumovsky; F. 379, no. 66, mid. $17^{\text {th }}$ century (1648-50), Service Menaion JuneAugust, kryuki, p. 413,41445.

44. The Hagiography and Miracles of St. Nicholas the Wonderworker, Archbishop of Mirliki and his Glory in Russia / Comp. A.Voznesensky and F.Gusev. Repr. ed. St.Petersburg: Tsar. Delo Publishing House, 1999. Pp. 226-247.

45. The music scoring for the troparion «Chudnoye i slavnoye Rozhdestvo tvoye...» was made by Alexander Igorevich Yushin. 


\section{REFERENCES}

1. Brazhnikov, M.V. 1984. Litsa i fity znamennogo raspeva: issledovanie / obshch. red. N.Sereginoy, A.Kryukova [Litsas and Fitas of the Znamennyi Chant: Research] obshch. red. N. Sereginoy, A. Kryukova [overall edit. by N.Seregina, A.Kryukov]; Predisl. N.Sereginoy [the foreword by N.Seregina]. Leningrad: Muzyka. Leningr. otd-nie [Leningrad: Music. Leningrad's department], p. 302 (in Russian)

2. Vereshchagina, N.V. 2004. "Chudotvornyy obraz Nikoly Mokrogo v vostochnoslavyanskoy kulturnoy traditsii" ["Miraculous Image of Saint Nicolas as a Part of Eastern-Slavic Cultural Tradition"], Pravilo very i obraz krotosti...Obraz svt. Nikolaya, arkhiepiskopa Mirlikiyskogo, v vizantiyskoy i slavyanskoy agiografii, gimnografii $i$ ikonografii [The Rule of Faith and the Image of Meekness... The Image of St. Nicholas, the Archbishop of Myra, within Byzantian and Slavic Hagiography, Hymnography and Iconography], red. A.V.Bugaevskiy [edited by A.V.Bugaevskiy], Moscow, pp. 403-412. (in Russian)

3. Zhitie i chudesa sv. Nikolaya Chudotvortsa, arkhiepiskopa Mirlikiyskogo i slava ego v Rossii, Sost. A. Voznesenskiy i F. Gusev [Hagiography and Miracles of Saint Nicolas, the Archbishop of Myra and his Fame in Russia, Compiled by A. Voznesenskiy and F. Gusev]. Repr. izd [Reprinted edition]. SPb.: Tsar. Dblo [Saint Petersburg: Tsar. Dblo Publishing house], 1999. p. 723. (in Russian)

4. Zernova, A.S. 1958. Knigi kirillovskoy pechati izdannye v Moskve v XVI-XVII vekakh [Books of Cyrillic Printing Published in Moscow in the $18^{\text {th }}-19^{\text {th }}$ Centuries]. M-vo kultury RSFSR, Gos. ordena Lenina B-ka SSSR im. V. I. Lenina, Otdel redkikh knig [Ministry of Culture of the Russian SFSR, Lenin State Library of the USSR, Rare Books Department]. M.: Tip. B-ki im. V. I. Lenina [Moscow: Publishing house of the State Library of the USSR]. p. 150. (in Russian)

5. Krutova, M.S. 1997. Svyatitel Nikolay Chudotvorets $v$ drevnerusskoy pismennosti [Saint Nicolas in Old Russian Writing]. M.: Martis [Moscow: Martis Publishing house], p. 222. (in Russian)

6. Kositskaya, A.Ye., Levshina, Zh.L. 2013. "Gimnografiya Area Orthodoxa v proekte «Liturgicheskoe nasledie Pravoslavnoy Tserkvi». Tseli i zadachi proekta. Arkheografiya i istochnikovedenie" ["Area Orthodoxa Hymnography as a Part of the Liturgical Legacy of the Orthodox Church Project'], Staroblgarska literatura, kn. 47 [OldBulgarian Literature, book 47], pp. 391-406. (in Russian)

7. Loseva, O.V.2001. Russkie mesyatseslovy XI-XIV vekov [Russian Menology of $11^{\text {th }}-14^{\text {th }}$ Centuries]. M.: Pamyatniki ist. Mysli [Moscow: Publishing house of Mysli as a part of historical heritages], p. 419. (in Russian)

8. Mineya sluzhebnaya. Iyul: Ch. 3 [Liturgical menation. July, part 3]. M.: Moskovskaya Patriarkhiya [Moscow: Publishing house of Moscow Patriarchy]. 1988. p. 416. (in Russian)

9. Mineya sluzhebnaya. Sentyabr [Liturgical menation. September]. M.: Moskovskaya Patriarkhiya [Moscow:
Publishing house of Moscow Patriarchy]. 1978. p. 502. (in Russian)

10. Minei: obrazets gimnograficheskoy literatury i sredstvo formirovaniya mirovozzreniya pravoslavnykh, pod red. Ye. Potekhinoy i A. Kravetskogo [Menations: an Example of Hymnographic Literature and a Means of Forming the Worldview of the Orthodox, edited by Ye. Potekhinoy and A. Kravetsko]. Olsztyn [Olsztyn], 2013. p. 204. (in Russian)

11. Boris Nikolaev, prot. Znamennyj raspev i krjukovaja notacija kak osnova russkogo pravoslavnogo cerkovnogo penija. Opyt issledovanija melodiki i notacii russkogo pravoslavnogo cerkovnogo penija so storony tserkovno-bogosluzhebnoj [Znamennyi Chant and Kryuki Notation as the Foundation of Russian Orthodox Liturgical Chant. Experience in the Study of Melodics and Notation of Russian Orthodox Liturgical Chant from the Church Liturgical Perspective], Iosifo-Volots. monastyr, O-vo drevnerus. muzyk. Kultury [Joseph-Volokolamsk Monastery, Old-Russian Musical Culture Society]. M.: Nauch. kn.: Talan [Moscow: Talan Scholarly Book]. 1995. p. 300. (in Russian)

12. Pavlova (Cherkasova), S.A. 2020. "Otechestvennaya gimnografiya svyatitelyu Nikolayu: novye materialy", Uchenye zapiski Rossiyskoy akademii muzyki imeni Gnesinykh, red. I. S. Stogniy [Russian Hymnography to Saint Nicholas: New Materials, Scholarly notes of Gnessin Russian Academy of Music, edited by I.S.Stogniy], Moscow, vol.34, no. 3, pp. 49-64 (in Russian)

13. Pavlova (Cherkasova), S.A. 2020. "Soderzhanie gimnograficheskikh tekstov kak osnova ikh pevcheskoy interpretatsii" ["Content of Hymnographic Texts as a Basis for their Cantatory Interpretation"], Uchenye zapiski Rossiyskoy akademii muzyki imeni Gnesinykh [Scholarly notes of Gnessin Russian Academy of Music], Moscow, vol. 34, no.3, pp. 92-106 (in Russian)

14. Ramazanova, N.V. 2004. Moskovskoe tsarstvo v tserkovno-pevcheskom iskusstve XVI-XVII vekov [Moscow Tsardom in Church Singing]. SPb.: «Dmitriy Bulanin» [Saint Petersburg: Dmitry Bulanin Publishing house ]. p. 453. (in Russian)

15. Rostovskiy Dmitriy, svt. Knigi zhitiy svyatykh, 4-ya chetvert: lyun-avgust [Hagiographies, ${ }^{\text {th }}$ Quarter: June-August]. Kiev: Tip. Kievo-Pecherskoy lavry [Kiev: Publishing house of Kiev Pechersk Lavra]. 1764. p. 604. (in Russian)

16. Sambikin Dmitriy, Archbishop. Mesyatseslov svyatykh, vsey Russkoy tserkovyu ili mestno chtimykh i ukazatel prazdnestv $v$ chest ikon Bozhiey Materi i sv. ugodnikov Bozhiikh v nashem otechestve [Menology of Saints, Worshiped by both Russian and Local Churches, as well Being a Calendar for Festivities in Honor of the Icon of Divine Mother and God's Saints in our Homeland]. Kamenets-Podolsk: tip. Podol. gub. pravl [Kamianets-Podolsk: Publishing house of the provincial government]., 1893-1902. Vyp. 11: Iyul [Edition of 11 July]. 1901. p. 377. (in Russian) 
17. Semenenko-Basin, I.V. 2009. "Pochitanie russkikh svyatykh: proekt Afanasiya Sakharova v istoricheskom kontekste" ["Worshiping of Russian Saints: a Project of Afanasiy Sakharov in Historical Context"], Kulturnaya zhizn Yuga Rossii [Cultural life of the South of Russia], Krasnodar: Krasnodarskiy gosudarstvennyy institut kultury [Krasnodar: Publishing house of Krasnodar State Cultural Institute], vol.30, no.1, pp. 61-63 (in Russian)

18. Spasskiy Sergiy, Archbishop. Polnyy mesyatseslov Vostoka [Full Menology of the East]. M.: Tserkov.-nauch. tsentr «Pravoslav. entsikl.»: Pravoslav. Palomnik [Moscow: Publishing house of the Orthodox Encyclopaedia Theological Scholarly Venue: Orthodox Piligrim]. 1997. Vol. 2: Svyatoy Vostok [The Saint East]. XXX, p. 398. (in Russian)

19. Sreznevskiy, I.I. Materialy dlya slovarya drevne-russkago yazyka po pismennym Pamyatnikam [Materials for OldRussian Dictionary Based upon Written Records]. SPb.: izdanie Otd-niya rus. yaz. i slovesnosti Imperatorskoy akad. Nauk [Saint Petersburg: Publishing house of the Imperial Academy of Sciences, Russian Language department]. 1890-1906. Vol. 2: L - P. 1895-1902. p. 1802. (in Russian)
20. Fasmer, M. 1996. Etimologicheskiy slovar russkogo yazyka: V 4 t. / Per. s nem. i dop. O. N. Trubacheva. 3-e izd., ster [Etymologicon of the Russian Language in Four volumes / translated and supplemented by O.V. Trubacheva. $3^{\text {rd }}$ edition]. M.: Izd. tsentr «Terra» [Moscow: Terra Publishing house]. vol. 3, p. 830. (in Russian)

21. Cherkasova, S.A. 2006. "Gimnografiya svyatitelyu Nikolayu: k voprosu o sisteme peniya na podoben" [Hymnograhpy to Saint Nicholas: to the Issue of the Chanting System by the Principles of Podobnys], Svyatitel Nikolay Mirlikiyskiy v pamyatnikakh pismennosti i ikonografii [Saint Nicholas in Literary Texts and Iconography], otv. red.-sost. G. S. Klokova, M. S. Krutova, [Composed and edited by G.S.Klokova, M.S.Krutova]. M.: Pravoslavnyy Svyato-Tikhonovskiy Gumanitarnyy Un-t, (M.: Tipografiya «Nauka») [Moscow: Nauka Publishing house, Saint Tikhon's Orthodox University], pp. 126149. (in Russian)

22. Cherkasova, S.A. 2008. Russkie sluzhby Rozhdestvu svyatitelya Nikolaya [Russian Church Services in Worshiping of Saint Nicholas], vol.51, no.1, pp. 285-298; vol. 52, no. 2, pp. 307-327. (in Russian) 


\section{ТРОПАРИ И КОНДАКИ РОЖДЕСТВУ СВЯТИТЕЛЯ НИКОЛАЯ В ОТЕЧЕСТВЕННЫХ РУКОПИСНЫХ И ПЕЧАТНЫХ КНИГАХ}

Аннотация: Настоящая статья вызвана счастливым обстоятельством. В рукописи сер. XVII века из Собрания прот. Д.В. Разумовского, Ф. 379 № 66 Российской государственной библиотеки, обнаружена нотированная запись тропаря Рождеству святителя Николая гл. 4 «Чудное и славное рождество твое...». Тропарь записан знаменным распевом в крюковой нотации. На сегодняшний день это единственный нотированный список не только тропаря, но в целом гимнографии Рождеству свт. Николая.

В статье распев приводится в оригинальной записи «истинно православной мелодии - спасительной и душеполезной», как говорит о знаменном распеве прот. Борис Николаев ${ }^{1}$. Параллельно выписан предложенный автором статьи перевод беспометной крюковой нотации на пятилинейную. Он сделан на основе анализа попевок из двоезнаменников XVIII в. и свода лиц и фит М.B. Бражникова ${ }^{2}$. Перевод беспометной записи представлен в качестве гипотезы звучания распева.

Публикацию предваряет краткое исследование о тропарях и кондаках праздника, об их содержании и положении в отечественных рукописных

1. Николаев Борис, прот. Знаменный распев и крюковая нотация как основа русского православного церковного пения: Опыт исслед. методики и нотации рус. православ. церков. пения со стороны церковно-богослужебной / Иосифо-Волоц. монастырь, О-во древнерус. музык. культуры. М.: Науч. кн.: Талан. 1995. С. 31.

2. Бражников М.В. Лица и фиты знаменного распева: исследование / общ. ред. Н. Серегиной, А. Крюкова; [Предисл. Н. Серегиной]. Л.: Музыка. Ленингр. отд-ние, 1984. С. 112120. и печатных книгах. Эти вопросы представляются важными на пути возвращения песнопений Рождеству свт. Николая в жизнь соотечественников и практику богослужения. Тропари и кондаки представлены во всём известном на сегодняшний день объёме. Это девять памятников отечественной гимнографии, выявленных в источниках периода кон. XVI - XIX вв.

Ключевые слова: гимнография, тропарь, кондак, Рождество святителя Николая, житие и чудеса, знаменный распев, беспометная нотация.

В новейшее время о празднике Рождества свт. Николая стало известно из печатных Миней 1978-1989 гг. ${ }^{3}$ Эта серия богослужебных книг была подготовлена по благословению Святейшего Патриарха Московского и всея Руси Пимена к торжественному празднованию 1000-летия Крещения Руси.

Издание уникально по объему собранных вместе русских памятей и гимнографии в сравнении с теми печатными книгами, что были известны прежде 4 . Руководитель Издательского отдела Московского Патриархата архим. Иннокентий (Просвирин) писал: «Новое издание Миней воплощает в жизнь замыслы многих поколений русских людей, стремившихся передать в той или иной форме рукописной традиции самобытное русское пре-

3. Минея служебная. Июль: Ч. З. М.: Московская Патриархия 1988. С. 297.

4. Минеи: образец гимнографической литературы и средство формирования мировоззрения православных / под ред. Е. Потехиной и А. Кравецкого. Olsztyn, 2013. С. 36-42. 
дание о своих святых, составляющих нетленную структуру Церкви» 5 .

В своей работе сотрудники Издательского отдела Московского Патриархата под председательством митр. Питирима (Нечаева) опирались на труды Богослужебно-календарной комиссии при Священном Синоде 1953-1958 гг., которую возглавлял и вдохновлял ныне прославленный в лике новомучеников и исповедников Российских свт. Афанасий (Сахаров). Комиссия, в свою очередь, по благословению Святейшего Патриарха Алексия I исполняла постановления Поместного Собора 1917-1918 гг. ${ }^{6}$ Таким образом, Минеи 1978-1989 гг. подытожили опыт исследователей и собирателей русского литургического творчества последнего столетия.

Издание богослужебных Миней не только по возможности обобщило достижения прошлого века, но послужило отправной точкой исследований века настоящего. Оно стало мерилом, с которым соотносят свою работу учёные в разных областях древнерусской традиции - гимнографии, эортологии, агиографии, иконографии. «Пименовские» Минеи (как их называют в обиходе) неоднократно дополнялись. На их основе были осуществлены следующие издания. По благословению Патриарха Московского и всея Руси Алексия II была издана серия Миней с сентября по август (2002), Минея Дополнительная в 2-х томах (2005). По благословению Патриарха Московского и Всея Руси Кирилла увидела свет новая Минея Дополнительная в 2-х томах (2018).

Праздник «Рождество святителя Николая, архиепископа Мир Ликийских» отмечен в Минеях, начиная с издания 1978-1989 гг. «Месяца июля в 29 день» выписаны тропарь, гл. 4 «Чудное и славное рождество твое...» и кондак, гл. 2, подобен: В мирех святе «В Мирех рождься святе Нuколае...». ${ }^{7}$ В начале $\mathrm{XX}$ века ещё одно печатное издание содержало память Рождества Святителя. Это «Месяцелов святых всею Русскою Церковию или местно чтимых <...>», составленный архиеп. Димитрием (Самбикиным). Месяцеслов издан в 1901 году «по благословению местного епархиального начальства» в качестве прило-

5. Минея служебная. Сентябрь. М.: Московская Патриархия. 1978. С. 7.

6. Семененко-Басин И.В. Почитание русских святых: проект Афанасия Сахарова в историческом контексте // Культурная жизнь Юга России. № 1 (30). Краснодар: Краснодарский государственный институт культуры. 2009. С. 61-63.

7. Минея служебная. Июль... С. 297. жения к Тверским епархиальным ведомостям. ${ }^{8}$ В библиографии праздника Рождества свт. Николая составители Миней 1978-1989 гг. ссылаются на этот источник, в нем опубликованы те же тропарь и кондак.

Другие печатные богослужебные книги, в которых отмечен праздник Рождества свт. Николая, нам не известны. ${ }^{9}$ До XX века традиция празднования передавалась в рукописях.

Рукописная история праздника охватывает семь столетий - с XIII по XIX вв. В период XIII-XV вв. Рождество свт. Николая упоминается в церковных календарях, болгарских и русских. ${ }^{10} \mathrm{C}$ XVI века в отечественных источниках записывается гимнография праздника. Это и отдельные песнопения, и богослужебные последования - службы с праздничными стихирами и каноном. О русских службах Рождеству свт. Николая мы рассказывали в одноименной статье. ${ }^{11}$ Нынешняя работа о главных песнопениях праздника - тропарях и кондаках. ${ }^{12}$

8. Самбикин Дмитрий, архиеп. Месяцеслов святых, всей Русской церковью или местно чтимых и указатель празднеств в честь икон Божией Матери и св. угодников Божиих в нашем отечестве: Вып. 1-12 [в 14 т.]. Каменец-Подольск: тип. Подол. губ. правл., 1893-1902. Вып. 11: Июль. 1901. С. 342.

9. Исследование печатных книг проводилось по списку, представленному в кн.: Зернова А.С. Книги кирилловской печати, изданные в Москве в XVI-XVII веках. М-во культуры РСФСР, Гос. ордена Ленина Б-ка СССР им. В.И. Ленина, Отдел редких книг. М.: Тип. Б-ки им. В.И. Ленина. 1958. 150 с В научных Описаниях рукописей встречаются указания на печатный первоисточник. Например, в Описании Собрания рукописных книг Н.С. Тихонравова (М., 1977) значится: «Ф. 299, № 484.1, 1723 г., Сборник житий, чудес свт. Николая и служб ему. Без начала и конца. Список с печатного?»; в Описании Собрания рукописных книг А.И. Маркушевича (М., 1982) обозначено: «Ф. 755, № 16, Святчцы (список с издания М., 1648 г.) и Устав в христианском житии». Однако, при сопоставлении рукописных и печатных источников (в тех случаях, когда они указаны) оказалось, что печатные издания памяти Рождества свт. Николаю не содержат.

10. Спасский Сергий, архиеп. Полный месяцеслов Востока: [В 3 т.] / Т. 2: Святой Восток. М.: Церков.-науч. центр «Православ. энцикл.»: Православ. паломник. 1997. С. XXIII, 137. Лосева О. В. Русские месяцесловы XI-XIV веков. М.: Памятники ист. мысли, 2001. С. 123, 413.

11. Черкасова С.А. Русские службы Рождеству святителя Николая // Альфа и Омега. М., 2008. №1(51). С. 285-298.

12. В изучении рукописной традиции мы опирались на корпус материалов Отдела рукописей Российской государственной библиотеки. Были просмотрены книги разных видов, в которых могла бы сдержаться не только гимнография, но любое упоминание праздника: Месяцесловы, Часословы, Святцы, Уставы, Псалтири, Иконописные подлинники, Сборники и Певческие рукописи. По каждому Собранию рукописей РГБ составлен список источников эортологии и гимнографии Рождества свт. Николая.

Точкой отсчета для нас послужил «Список рукописей с произведениями о Святителе Николае в собрании ОР РГБ», составленный М.С. Крутовой. Среди памятников агиографии в Списке отмечены две рукописи со службами Рождеству 
В рукописных источниках XVI-XIX вв. записано тропарей и кондаков девять песнопений. ${ }^{13}$ Перечислим их с указанием самого раннего списка текста:

Тропарь, глас 4

"Oтечество свое и рожение и воспитание..." (Ф. 209, № 390, XVIв., Устав)

Тропарь, глас 4

«Преславному рождеству твоему

ангельстий чинове....»

(Ф. 199, № 118, 1615г., Святцы)

Тропарь ${ }^{14}$, глас 2

«Церкви твоя Господи светло празднуют...» (Ф. 199, № 118, 1615г., Святцы)

Тропарь, глас 4

«Тайно дерзновенне уподобился еси мудре...» (Ф. 98, № 209, XVIIв. (до 1606 г.) Устав)

Тропарь, глас 4

"Чюдное и славное рожество твое...»

(Ф. 379, № 66, XVIIв. Минея июнь - август, на крюках)

Тропарь, глас 2

"Днесь возсия нам яко солнце

торжество твое...»

(БАН Вятское собрание, № 66, XVIII в. Сборник служб)

Кондак, глас 3

«Взыде яко звезда от востока и до запада

Свт. Николая. См.: Крутова М.С. Святитель Николай Чудотворец в древнерусской письменности. М.: Мартис, 1997. C. 152.

13. Благодарим за помощь в источниковедческой работе руководителя проекта «Литургическое наследие Православной Церкви» внештатного сотрудника Синодальной богослужебной комиссии О.В. Ладу. Подробнее о проекте см: Косицкая А., Левшина Ж. Гимнография Area Orthodoxa в проекте «Литургическое наследие Православной Церкви». Цели и задачи проекта. Археография и источниковедение // Старобългарска литература, Кн. 47, 2013. С. 391406.

14. В рукописи обозначен как «кондак, глас 2». Выписанный перед этим текстом кондак «В мире рожейся...» обозначен как «другой тропарь, глас 2». Вероятно, переписчик перепутал и поменял местами тексты «В мирех рожейся...» и «Церкви Твоя Господи...». Таким образом, текст «Церкви твоя Господи...» должен быть обозначен как «другой mропарь, глас 2» - это правильно. Текст «В мирех рожейся...» должен быть обозначен как «кондак, глас 2» - это правильно. В списке текстов, приведённых в статье, ошибка исправлена. твое рожение и воспитание...»

(Ф. 209, № 390, XVIв., Устав)

\section{Кондак, глас 2}

«В мирех рожейся святый Николае

от благородна корене...»

(Ф. 199, № 118, 1615г., Святцы)

Кондак, глас 3

«Якоже в рождестве возсиял еси

Духом Пресвятым...»

(Ф. 199, № 457, XVIIв., Устав)

Тропари и кондаки встречаются в рукописях в разных комбинациях. Например, кондак, гл. 2 « $B$ мирех рожейся святе Николае...» выписывается со всеми известными тропарями ${ }^{15}$; кондак, гл. 3 «Взыде яко звезда от востока до запада рождение твое...» только с тропарем, гл. 4 «Отечество твое и рождение и воспитание...»; тропарь, гл. 4 «Преславному рождеству твоему ангельстий чинове...» вместе с «другим тропарем», гл. 2 «Церкви Твоя Господи светло празднуют...» и т. д. Мы посмотрели на песнопения со стороны содержания. С этой точки зрения тропари и кондаки можно объединить в три группы. ${ }^{16}$

Первая - включает тексты, составленные на основе жития свт. Николая, называемого по имени автора «Метафрастовым». "Житие написано в Х в. византийским агиографом, преп. Симеоном Метафрастом. Этот тип жития <... > включен свт. Макарием, митрополитом Московским и всея Руси в Великие Минеи Четьи». ${ }^{17}$

Вторая группа песнопений опирается на так называемое «иное» житие. Этот тип жития также принадлежит греческой агиографической традиции. "Текст известен у нас с XI века. На русский язык, как считали некоторые ученые, оно было переведено преп. Ефремом Печерским. Епископом Переяславским». ${ }^{18}$

Третья группа - это гимнография, которая составлена на основе отечественного опыта почитания свт. Николая. В её содержании переданы самые общие, но важные для русского духовно-

15. Кроме тропаря, гл. 4 «Отечество твое и рождение и воспитание...», который выписан с кондаком, гл. 3 «Взыде яко звезда от востока и до запада твое рожение и воспитание...».

16. Подчеркнем, что разделение на группы условное. Оно сделано в рамках исследования.

17. Сведения по агиографии и публикации разных типов жития свт. Николая см.: Крутова М.С. Указ. соч.

18. Там же. С. 120-127. 
го творчества образы и мысли, отражена история нашей христианской культуры.

Последовательно расскажем о песнопениях каждой условно обозначенной группы.

\section{1. Песнопения по «Метафрастову» житию свт. Николая.}

К первой группе относятся тропарь, гл. 4 «Тайно дерзновение уподобился еси...» и кондак, гл. 2 «В мирех рожейся святе Николае...». Эти песнопения наиболее часто встречаются в рукописях. Они выписываются не только отдельно, но и в составе служб на Рождество свт. Николая (тропарь представлен в четырех из пяти списков службы) ${ }^{19}$. Кондак «В Мирех рождься...» вошел в печатные издания XX века.

Мы сравнили тропарь «Тайно дерзновение уподобился еси...» с соответствующими песнопениями на праздник Перенесения мощей свт. Николая $\left(9 / 22\right.$ мая ${ }^{20}$. Напомним, что эта русская память была внесена в церковный календарь вскоре после самого события 1087 года и встала в один ряд с греческой памятью Преставления свт. Николая (6/19 декабря). Сравнение показало, что текст рождественского тропаря встречается также в гимнографии на Перенесение мощей. Время записи тропаря в контексте этого праздника ограничивается XVI веком ${ }^{21}$. С начала XVII в. он выписывается среди песнопений Рождества свт. Николая.

19. РГБ. Ф. 98, № 903, 1657 г., Сборник житий и служб, л. 368 368об.; Ф. 299, № 484.1, 1723 г., Сборник житий, чудес свт. Николая и служб ему (русского происхождения), л. 215; Ф. 37, № 438, XIX в., Сборник служ6, преимущественно русским святым, л. 467 об.; Ф. 98, № 1510, XIX в., Трефолой март - август, л. 145 об. Из перечисленных источников первые два указаны в кн.: Крутова М.С. Указ. соч. Текст службы по этим спискам опубликован (в современной орфографии): Черкасова С.А. Русские службы Рождеству святителя Николая...

20. Словосочетание «Тайно дерзновение уподобился...» приводится по списку РГБ, Ф. 98, № 209, нач. XVII в (1606 г.), Устав церковный, л. 502 (он самый ранний в ряду источников записи тропаря), также текст представлен в списке Ф. 98, № 903, 1657 г., Сборник житий и служб, л. 368-368об.; РГБ, Ф. 98, № 1510, XIX в., Трефолой март - август, л. 146-146 об. В рукописях встречаются и другие варианты прочтения: «Тайнодерзновенне уподобился...» - РГБ, Ф. 299, № 484.1, 1723 г., Сборник житий, чудес свт. Николая и служб ему (русского происхождения), л. 215; «Дерзновению уподобился...»- РГБ, Ф. 37, № 438, XIX в., Сборник служб преимущественно русским святым, л. 466.

21. В певческой традиции праздника Перенесения мощей этот тропарь больше известен в следующем варианте: «Ильину оуподобися дерзновению мудре...». В певческой традиции праздника Перенесения мощей этот тропарь больше известен в следующем варианте: «Ильину оуподобися дерзновению мудре...» Тропарь «Ильину оуподобися...» поло-
Приведем текст тропаря по самому раннему обнаруженному нами списку Ф. 98, № 209, XVII в. (до 1606 г.) Устав: «Тайнодерзновение оуподобился еси мудре. Царя бо обличилъ еси ангелом двократы. избави три моужи от смерти. темъ по оуспении твоемъ сияеши чюдесы. отче наш святителю Николае. моли Христа Бога спастися душам нашим».

Содержание тропаря «Тайно дерзновенне оуподобился еси мудре...» связано с греческой традицией почитания свт. Николая, а именно с прославлением Святителя в связи с чудом о спасении трех воевод. Нам приходилось писать об этом, поэтому повторим здесь самое главное. ${ }^{22}$ Деяние о стратилатах (такое название имеет чудо в греческой традиции) - древнейшее из записанных чудес свт. Николая. Оно послужило не только основой агиографии Святителя, но и главным сюжетом песнотворчества. Более того, в греческой гимнографии сложилось догматическое толкование чуда. В спасении от смерти воевод, заключенных в темницу по навету завистников, песнотворцы прославили Спасительные деяния Христа, Его Домостроительство. ${ }^{23}$

Деяние о стратилатах представляет свт. Николая не только спасителем обратившихся к нему воинов, но и окормителем равноапостольного царя Константина, ошибочно наказавшего своих верных слуг. Свт. Николай дважды является во сне царю с наставлением, ожидая от него послушания (в другом похожем чуде из жития Святителя - об избавлении трех мужей от усечения мечом, спасение совершается мгновенно). Мотив заступничества и покровительства Святителя законной княжеской власти в русской традиции попадает на плодотворную духовную почву. ${ }^{24}$ В празднике

жен на 2-й глас, «Тайно дерзновенне оуподобися...»- на 4-й. Отличие гласа в этом случае свидетельствует об изменении в содержании текста и, по сути, о появлении нового тропаря. Подробнее см.: Павлова (Черкасова) С.А. Содержание гимнографических текстов как основа их певческой интерпретации // Ученые записки Российской академии музыки имени Гнесиных / ред. И.С. Стогний. М. 2020. № 3 (34). C. 92-106.

22. Черкасова С.А. Русские службы Рождеству святителя Николая.

23. Черкасова С.А. Гимнография святителю Николаю: к вопросу о системе пения на подобен // Святитель Николай Мирликийский в памятниках письменности и иконографии / [отв. ред.-сост. Г.С. Клокова, М.С. Крутова]. М.: Православный Свято-Тихоновский Гуманитарный Ун-т, 2006 (М.: Типография «Наука»). С. 126-149.

24. Для этого есть все исторические основания: образ «Николы Мокрого», "возможно, был в числе первых византийских даров новокрещенному русскому князю Владимиру» («икона могла прибыть в Киев в числе первых сакральных 
Перенесения мощей, в стихирах Рождеству свт. Николая, особенно в песнопениях чудотворным иконам Святителя, тема развивается настойчиво и уверенно. Помимо особенного внимания к чуду о спасении трёх воевод и явлении во сне Константину царю, в русской духовной традиции талант свт. Николая прославляется обобщённо: «князем окормитель...».

Кондак, гл. 2 «м мирех рожейся святе Николае...» составлен по образцу кондака гл. 3 «В мирех святе святитель явился еси...» на праздник Преставления свт. Николая (6/19 декабря). Напомним, что праздник Преставления был унаследован русской церковью от греческой. Соблюдая греческую традицию, гимнограф мастерски её обновляет, разворачивая текст навстречу событию Рождества. ${ }^{25}$

Остановимся на двух редакциях рождественского кондака. Первая представлена в рукописях 1-й пол. XVII века. Вторая - со 2-й пол. XVII века вплоть до современных печатных Миней. ${ }^{26}$ Сравним редакции текстов:

\section{Первая редакция}

Кондак, глас 2

РГБ. Ф. 199, № 118, 1615 г., Святцы

В мирех рожейся, святый Николае

от благороднаго корене

боголюбимаго отца Феофана.

из ложесн боголюбимыя 27

матери Ноны.

реликвий как из самого Константинополя в составе приданого принцессы Анны, супруги Владимира $\langle\ldots\rangle$, так и из Корсуни <... >». См.: Верещагина Н В. Чудотворный образ Николы Мокрого в восточнославянской культурной традиции // Правило веры и образ кротости... Образ свт. Николая, архиепископа Мирликийского, в византийской и славянской агиографии, гимнографии и иконографии ред. А.В. Бугаевский. М., 2004. С. 408.); образ «Николы Липенского» исцелил кн. Мстислава Всеволодовича; «Никола Зарайский» явился, открыв врата Царствия Небесного семье Феодора Игоревича, князя г. Красного (Заразска); образ свт. Николая «угреша сердце» св. блгв. кн. Димитрия Ивановича (Донского); образ «Николы Великорецкого» укрепил Иоанна Васильевича VI в Казанском походе и т. д.

25. Павлова (Черкасова) С.А. Содержание гимнографических текстов...

26. В печатной Минее 1978-1989 гг. кондак «В Мирех рождься...» выписан с указанием: глас 2, подобен В Мирех святе. См.: Минея служебная. Июль... С. 297. В рукописной традиции иначе. Обозначение гласа отличается. В разных источниках могут быть указаны гласы 2-й или 3-й. В период XVII-XVIII вв. кондак «В Мирех рождься...» выписывается без указаниея на подобен. Обозначение подобна появляется в рукописях XIX века.

27. «...богонравныя утрообы...» (РГБ. Ф. 98, № 903, 1657; РГБ Ф. 299 № $484.1,1723$ ) проразумел еси путь спасения

исполнися божественных чудес

быв святитель

преподобный Николае.

и пречюден учеником явлься

Божественныя благодати.

Вторая редакция

Кондак, глас 2. Подобен: В Мирех святе. Минея

2002 г.

В Мирех рождься,

святый Николае,

от благородна корене,

яко благоплодна ветвь,

прозябл еси,

исполнь бо быв Божественных даров

яко солнце зарями,

весь мир чудесы просветил еси,

сего ради прославляем тя,

яко ученика и таинника

Божия благодати.

В центре песнопения первой редакции - тема спасения и чудотворения: «...nроразумел еси путь спасения исполнися божественных чудес...». Она переходит в рождественский кондак из подобна, кондака на Представление свт. Николая. В подобне соответствующая строка текста звучит так: «спасл еси неповинныя от смерти сего ради освятися...», в этой строке два чуда, следующих в житии Святителя одно за другим - о спасении трёх мужей от усечения мечом и трех воевод от темницы - представлены обобщённо: «спасл еси неповинныя от смерти...».

Во второй редакции рождественского кондака смысловая цепочка, идущая от подобна прерывается. Вместо строки подобна «...спасл еси неповинные от смерти...» (осмысленной в первой редакции текста как «...nроразумел еси путь спасения...») во второй редакции поется: «...яко благоплодная ветвь прозябл еси...». Что произошло? Редактор заменил прославление конкретных деяний свт. Николая распространённым в гимнографии оборотом о «благоплодной ветви...». Напомним, прочтение этих чудес в грече- 
ской гимнографии (вслед за этим в отечественной) подразумевало догматическую составляющую.

Прославление спасительных деяний свт. Николая, его дара чудотворений поставлено в определенный контекст. В начале песнопения - сказано о родителях, в завершении - о божественной благодати. Во второй редакции кондака неспешный рассказ о родителях свт. Николая сокращён. Остается обобщение: «...от благороднаго корене ...». Содержание в целом не меняется, но в частности - обезличивается. Пропевание конкретных имён и деяний давало время на обдумывание, а задуматься есть над чем.

Какими были родители свт. Николая, если «nуть спасения» будущий Святитель «проразумел» «...от благородного корени боголюбимого отиа Феофана. из ложесн боголюбимой матери Ноны...»? В житии Святителя о родителях говорится: «...некто благороден муж <... > ему же имя Феофан <...>. Супруга же бе ему Нона. Сие же благословеное супружество со всяким добронравием благочестия держащеся и во правоверной вере, яже во Христа Бога, присно хвалящеся...» ${ }^{28}$.

Важные подробности показывают, что рождение такого подвижника, каким был свт. Николай, глубоко связано с подвигом жизни его родителей, их «добронравием», «держанием благочестия», «правоверной верой во Христа». Об этом и поется в кондаке первой редакции.

Итак, в содержании тропаря, гл. 4 «Тайно дерзновение уподобился еси мудре...» и кондака, гл. 2 «В Мирех рождься святе Николае...» гимнографы опирались на греческую традицию воспевания свт. Николая, почерпнутую в «Метафрастовом» житии. Непосредственно это проявилось в прославлении чуда о спасении воевод и в воспевании родителей свт. Николая - Феофана и Ноны. В плане художественного слова и формы песнопений авторы ориентировались на соответствующие тексты двух известных праздников свт. Николая: русской памяти Перенесения мощей и греческой - Преставления Святителя. ${ }^{29}$

28. Крутова М.С. Указ. соч. С. 10-11.

29. Отметим также пересечения в содержании тропаря и кондака с гимнографией праздника Рождества Христова. В кондаке это связано с пением на подобен, имеется ввиду, что цепочка текстов через кондак праздника на Пренесение мощей свт. Николая восходит к кондаку Рождества Христова «Дева днесь». Тропарь же повторяет запоминающийся, яркий оборот речи в начале тропаря на паремии Рождества Христова «Тайно родился еси в вертепе...».
2. Песнопения по «иному» житию свт. Николая

К этой группе текстов относится самое большое количество песнопений: тропарь, гл. 2 «Церкви Твоя Господи светло празднуют...»; тропарь, гл. 4 «Чюдное и славное рождество твое...»; тропарь, гл. 2 «Днесь возсия нам яко солнце торжество твое...»; тропарь, гл. 4 «Отечество твое и рождение и воспитание...»; кондак, гл. 3 «Взыде яко звезда от востока до запада твое рождение и воспитание...».

Тропарь, гл. 4 «чюдное и славное рождество mвое...” так же, как и песнопения, представленные в предыдущей группе, в рукописных источниках встречается часто. Дважды он выписан в службах Рождеству свт. Николая. ${ }^{30}$

В процессе исследования выяснилось, что этот тропарь представляет собой редакцию «другого тропаря» на Рождество свт. Николая, гл. 2 «Церкви Твоя Господи светло празднуют...” ${ }^{31}$. Последний представлен единственным списком в рукописи нач. XVII в.: РГБ, Ф. 199, № 118, 1615 г., Святцы. Редакция была сделана до 1648-1658 гг. Именно этими годами датируется самый ранний источник, содержащий тропарь "Чудное и славное рождество твое...». Это рукопись из Собрания Д.В. Разумовского ф. 379, № 66, Минея за июнь - август. По типу книги она представляет собой т. н. «Дъячье око» - "существовавший еще в Студийскую эпоху и возрождающийся с середины XVI века стихирарь-образец» ${ }^{32}$. Д.В. Разумовский уточняет время создания рукописи: «Писана при царе Алексее Михайловиче <... > и при nampuapхе Иосифе <...> не ранее 1648го и не позднее 1658-го г2.». ${ }^{33}$ Именно в этом списке представлена нотированная запись тропаря, которая публикуется в настоящей статье.

Сопоставим тексты тропарей:

30. БАН, Вятское собрание, № 66, нач. XVIII в., Сборник житий и служб свт. Николаю; РГБ, Ф. 98, № 1510, XIX в., Трефолой март - август, л. 83об., л. 146.

31. В свою очередь тропарь «Чюдное и славное Рождество твое...», вероятно, послужил основой "другого тропаря», гл. 2 «Днесь возсия нам яко солнце торжество твое...» (БАН Вятское собрание, № 66, XVIII в.). В настоящей статье последний тропарь не рассматривается.

32. Рамазанова Н.В. Московское царство в церковно-певческом искусстве XVI-XVII веков. СПб.: «Дмитрий Буланин», 2004. C. 31.

33. См.: Описание Собрания рукописных книг Д.В. Разумовского. Фонд № 379. М.: РГБ, 1958. С. 85-86. 
Тропарь, гл. 2

РГБ Ф. 199, № 118, 1615 г.,

Святцы

Церкви Твоя Господи

светло празднуем

честнаго твоего рождества

отче Николае.

егда хощет тя баба омыти

стоянием твоея ноги

прослави тебя.

светилника и учителя миру.

яко своя родители удивил еси рожеством своим отче Николае.

моли Христа Бога

спастися душам нашим.

Тропарь, гл. 4 (редакция)

РГБ Ф. 379, № 66, 1648-1650 гг.,

Минея июнь - август, на крюках

Чюдное и славное рожество твое

святителю Николае.

церкви днесь Православных

светло празднуют.

ибо стоянием ногу твоею

яви тя Господь. и провозвести быти

светилника и учителя миряном.

весь мир обогащающа

и просвещающа чудесы

тем вопием тu

моли Христа Бога

спастися душам нашим.

В первых строках обозначено праздничное событие. В тропаре «Чюдное и славное рождество твое...» уточняется, что праздник светло празднуют «Церкви <...> Православные».

В срединных строках прославляется чудо о стоянии ног, совершённое младенцем по рождении. В «ином» житии свт. Николая сказано так: «...егда ж бо родитися, куплему ему в ночвах, ${ }^{34}$

34. «Ночвы-укр. корыто, лохань, русск. церк.-слав. нъщьвы <... >». Фасмер М. Этимологический словарь русского языка: В 4 т. / Пер. с нем. и доп. О.Н. Трубачева. 3-е изд., стер. М.: Изд. центр «Терра». 1996. Т. 3. С. 601.
Божиею силою ста на ногу своею прост до двою часу...». ${ }^{35}$ В тропаре «Церкви Твоя Господи светло празднуют...» гимнограф уточняет, что омовение младенца совершала «баба»: «....егда хощет тя баба омыти стоянием твоея ноги прослави тебя...". ${ }^{36}$ Возможно, такого рода особенности текста свидетельствуют о его древности. В варианте «Чюдное и славное рождество твое...» строка сокращена и отредактирована стилистически: «...ибо стоянием ногу твоею...».

Совершённое во младенчестве чудо воспевается как пророчество будущих талантов Святителя: «...рожество твое <... черкви днесь <...> светло празднуют, ибо стоянием ногу твоею яви тя Господь. и провозвести быти светилника и учителя миряном...». В этом обе редакции согласны.

В заключительных строках кондака первой редакции упомянуты родители свт. Николая: «... родителей удивил еси рожеством своим...». Во второй редакции о них речи не идёт, только о «всемирной» славе Святителя: «...весь мир обогащающа и просвещающа чудесы...». Такая «каденция» на тему всемирной славы, возможно, позволила песнотворцу изменить глас тропаря со 2-го (в первой ред.) на «всепраздневственный» 4-й (во второй ред.). ${ }^{37}$

На материалах «иного» жития построен ещё один тропарь, гл. 2, «Отечество твое и рождение и воспитание...». Он записан вместе с кондаком, гл. 3 «Взыде звезда от востока и до запада рождение твое и воспитание...". ${ }^{38}$

«Нецва: - Николая Чудотворьца помыти его хотящи, баба положи и в нецвах. Прол. 1432 г., л. 132». Срезневский И.И. Материалы для словаря древне-русскаго языка по письменным памятникам. СПб.: издание Отд-ния рус. яз. и словесности Императорской акад. наук. 1890-1906. Т. 2: Л - П. 1895-1902. 1802. С. 440.

35. Крутова М.С. Указ. соч. С. 95.

36. Слово «баба» употребляется в значении «повивальная баба». Срезневский И.И. Указ. изд. I, С. 31.

Интересны параллели с иконографией Рождества свт. Николая, в которой подразумевается изображение «бабы» (повитухи), которая либо держит младенца на руках у купели («ночвы»), либо находится рядом с ним в момент чудесного «стояния ног». «Иконописные подлинники» слово в слово повторяют песнотворца. Например, «егда начаша его омывати бе ночвах мало постоя» (РГБ Ф. 734, № 52, 1698 г., л. 177об.) или «егда стала его мати омывати в ногах мало постоя» (РГБ Ф. 579, № 42, XVIII в., л. 236; Ф. 178, № 3474, 2-я пол. XVIII в., л. 181 и др.). Слово «мати» появляется в текстах «Иконописных подлинников» только в XVIII веке

37. Николаев Борис, прот. Указ. соч. С. 94.

38. Публикацию текстов тропаря и кондака см.: Павлова (Черкасова) С.А. Отечественная гимнография святителю Николаю... С. 49-63. 
В составлении тропаря и кондака гимнограф ориентировался на одноимённые тексты (по первой строке) праздника Перенесения мощей свт. Николая (9/22 мая). Переложения сделаны с помощью замены отдельных слов и расширения, дополнения текста новыми строками. Например, вместо «Мир Ликийских» и «града Барского», как это было в песнопении на Перенесение мощей, составитель наносит на поэтическую «карту» топонимы Рождества свт. Николая из «иного» жития: «...Тарсакильский град...» (он же «Фарсис»), «...Каласиский монастырь...» (он же «Сион») и т. д. Многократное повторение топонимов наводит на мысль о дидактической направленности текста.

Гимнограф останавливается на чуде «прилежания к посту», совершённом свт. Николаем во младенчестве. Это чудо объединяет все «типы жития» и выписано в Великих Минеях Четьих свт. Макария. В тропаре поётся: «...и от матерних сосец не приимаше...». В житии уточняется: «...в среду бо и в пяток единою [от сосец] причащашеся млеку, и то же во время вечернее, еже по совершении Божественнаго правила...». 39 Это удивительное чудо показывает свт. Николая в Рождестве тем же подвижником, каким он является в Преставлении. Вспомним тропарь, гл. 4 «Правило веры...» и обращение к Святителю «...воздержанию учитель...».

Интересно представлена в этой паре песнопений тема праздника: «...твое рождение и восnитание...». В заключительных строках кондака уточняется: “...отрок в рождении своем и воспитании <... > предивен и милостив». В тропаре выписаны имена воспитателей: помимо «родителей» это "учитель и наставник Савватий» и «строитель Никола». В остальной гимнографии подчёркнуто, что свт. Николай уже в момент рождества и даже «во утробе матерней святительства прозвание приим...». Иными словами, его «воспитание» к моменту "рождения» уже совершилось. Это и являлось поводом для удивления и прославления свт. Николая в его Рождестве и, возможно, стало поводом к установлению праздника. Прославление «воспитания» нам более не встретилось ни в одном песнопении Святителю.

Итак, в тропарях и кондаках, написанных по «иному» житию свт. Николая, прославляются чудеса, совершённые «отроком предивным и ми-

39. Крутова М.С. Указ. соч. С. 11. лостивым» во младенчестве. В них гимнографы видят пророчества будущих талантов Святителя.

В качестве ориентира в составлении некоторых текстов выступают песнопения праздника на Перенесение мощей свт. Николая.

\section{3. Песнопения по отечественной славе свт.} Николая

Эту группу составили два текста: тропарь, гл. 4 «Преславному рождеству твоему ангельстий чинове...» и кондак, гл. 3 "Якоже в рождестве возсиял еси Духом Пресвятым...». Оба песнопения известны в единственном списке XVII в. (см. в начале статьи таблицу тропарей и кондаков с указанием рукописного источника).

Приводим текст тропаря, гл. 4 «Преславному рождеству твоему...»: «Преславному рождеству твоему ангельстий чинове немолчно воспеваем устны яко Господь хощет показати светилника и угодника своего Николу. зовем тебе прилежно все. Укрепи нас и вражию силу и советы упраздни поганых. на нас востающих безбожных врагов погуби . Божественным . Христовым повелением.»

Простой ясный взгляд. Мир, в котором все мы «немолчно воспеваем устны» и «зовем прилежно» свт. Николаю, представлен в христианской системе координат. «Долгота» это «...ангельстий чинове...» (к которому принадлежит свт. Николай). «Широта» - «...на нас востающие безбожные враги...». От описания врагов страшно. Они и «поганые», и сильные («вражья сила»), и «востающие», и «безбожные». Видно, что тропарь является отражением жизни, тревожной до глубины души.

Простая соборная мысль. «Никола» не сам по себе, но в «ангельстем чине»: «Преславному рождеству твоему ангельстий чинове немолчно воспеваем устны...». "Никола» не сам собою "светилник», но «...яко Господь хощет показати светилника и угодника своего Николу. зовем тебе прилежно все...». «Никола» не сам помогает, но «...Божественным . Христовым повелением».

В одной рукописи с тропарем «Преславному рождеству твоему ангельстий чинове...» выписан «другой тропарь», глас 2 «Церкви Твоя Господи светло празднуют...» (он рассмотрен в предыдущем разделе в связи с тропарем «Чюдное и славное твое рождество...»). Оба текста, вероятно, представляют древнейший пласт отечественной гимнографии Рождеству свт. Николая. 
«О тайнах Горнего мира мы знаем очень мало, и земными человеческими образами его передать нелегко, - пишет прот. Борис (Николаев) в связи с содержанием песнопений 3-го гласа. - Вот почему так мал круг песнопений этого гласа» ${ }^{40}$. Кондак, гл. 3 "якоже в рождестве возсиял еси Духом Пресвятым...” несомненно принадлежит этому «малому кругу».

«Земные человеческие образы» свт. Николая и его родителей открываются в песнопении во "светлостях будущего века» ${ }^{41}$ : «Якоже в рождестве возсиял еси Духом Пресвятым от Нонны и Феофана, ангелом показася законен, Христа ради родися, Николае, отроча младо славный, ангелом и пророком спожитель бысть с ними же Христа Бога моли непрестанно о всех нас».

Свт. Николай прославляется как «ангелом и пророком спожитель». Песнотворец «тихо радуется» тому, как Чудотворец с самого рождения «законно» молится вкупе с чинами небесными.

Родители свт. Николая прославляются в ряду Божественных имен - Христа и Пресвятого Духа: «...в рождестве возсиял еси Духом Пресвятым от Нонны и Феофана, ангелом показася законен, Христа ради родися...».

Ангельский образ почерпнут гимнографом в рождестве Святителя, в его младенческих чудесах. «Христа ради рожденный» младенец удивляет ангельским житием. Сами чудеса в песнопении не называются, о них мы знаем из жития: «..Божиею силою ста на ногу своею прост до двою часу...» ${ }^{42}$, «...в среду бо и в пяток единою [от сосещ] причащашеся млеку...» ${ }^{43}$. Житию вторит похвальная гимнография: «Ангела образом земнаго суща естеством...» (начало Акафиста свт. Николаю), «Ангелу благовестителю уподобился ты еси Нuколае...» (из Акафиста Зарайскому образу) и т. д.

Пророческий образ складывается отчасти в толковании младенческих чудес как показателей («...nоказа тя Господь...») будущей славы Святителя, отчасти переходит из гимнографии других праздников Свт. Николаю: «..яко вторый Предтеча на земли явился еси, святе отче Николае...» (Преставление, 6/19 мая), "Илиину подобися дерзновению мудре...» (Перенесение мощей, 9/22 мая). Для русской гимнографии эта тема важна. Явившись на Русь задолго до Крещения, свт. Николай

40. Николаев Борис, прот. Указ. соч. С. 94.

41. Там же. С. 94.

42. Крутова М.С. Указ. соч. С. 95

43. Там же. С. 11. выступил одним из первых пророков Христианства в нашем Отечестве. ${ }^{44} \mathrm{C}$ тех пор, в течение более тысячи лет «...Божественным . Христовым повелением» Свт. Николай предупреждает, укрепляет, защищает «люди своя».

Краткое исследование о главных песнопениях праздника - тропарях и кондаках показало богатую традицию почитания Святителя в его Рождестве. В содержании песнопений усвоено наследие греческой церкви и, вместе с тем, отражена собственная яркая христианская культура. Гимнографическое наследие праздника Рождества свт. Николая переживает в наши дни возрождение. Всё готово к тому, чтобы «...немолчно воспевать усты яко Господь хощет показати светилника и угодника своего Николу...».

Публикация: Тропарь, гл. 4. «Чудное и славное рождество твое...».

Отдел рукописей Российской государственной библиотеки, Собрание Д.В. Разумовского, Ф. 379, № 66, сер. XVII в. (1648-1650 гг.), Минея служе6ная июнь - август, на крюках, л. 413 об.-41445.

44. Житие и чудеса св.Николая Чудотворца, архиепископа Мирликийского и слава его в России/Сост. А.Вознесенский и Ф.Гусев. Репр.изд. СПб.:Цар. ДЬло, 1999.С. 226-247.

45. Нотный набор текста тропаря «Чудное и славное Рождество твое...» выполнил Александр Игоревич Юшин. 
1. Бражников М.В. Лица и фиты знаменного распева: исследование / Общ. ред. Н. Серегиной, А. Крюкова; [Предисл. Н. Серегиной]. - Л.: Музыка. Ленингр. отд-ние, 1984. - 302 с.

2. Верещагина Н.В. Чудотворный образ Николы Мокрого в восточнославянской культурной традиции // Правило веры и образ кротости... О6раз свт. Николая, архиепископа Мирликийского, в византийской и славянской агиографии, гимнографии и иконографии / Ред. А.В. Бугаевский. - М., 2004. - С. 403-412.

3. Житие и чудеса св. Николая Чудотворца, архиепископа Мирликийского и слава его в России / Сост. А. Вознесенский и Ф. Гусев. - Репр. изд. СПб.: Цар. ДБло, 1999. - 723 с.

4. Зернова А.С. Книги кирилловской печати, изданные в Москве в XVI-XVII веках. М-во культуры РСФСР, Гос. ордена Ленина Б-ка СССР им. В.И. Ленина, Отдел редких книг. - М.: Тип. Б-ки им. В.И. Ленина, 1958. - 150 с.

5. Крутова М.С. Святитель Николай Чудотворец в древнерусской письменности. - М.: Мартис, 1997. - 222 с.

6. Косицкая А.Е., Левшина Ж.Л. Гимнография Area Orthodoxa в проекте «Литургическое наследие Православной Церкви». Цели и задачи проекта. Археография и источниковедение // Старобългарска литература, кн. 47. - 2013. - С. 391-406.

7. Лосева О.В. Русские месяцесловы XI-XIV веков. - М.: Памятники ист. мысли, 2001. - 419 с.

8. Минея служебная. Июль: Ч. 3. - М.: Московская Патриархия, 1988. - 416 с.

9. Минея служебная. Сентябрь. - М.: Московская Патриархия, 1978. - 502 с.

10. Минеи: образец гимнографической литературы и средство формирования мировоззрения православных / Под ред. Е. Потехиной и А. Кравецкого. -Olsztyn, 2013. - 204 c.

11. Николаев Борис, прот. Знаменный распев и крюковая нотация как основа русского православного церковного пения: Опыт исслед. методики и нотации рус. православ. церков. пения со стороны церковно-богослужебной / Иосифо-Волоц. монастырь, О-во древнерус. музык. культуры. - М.: Науч. кн.: Талан, 1995. - 300 с.

12. Павлова (Черкасова) С.А. Отечественная гимнография святителю Николаю: новые материалы // Ученые записки Российской академии музыки имени Гнесиных / Ред. И.С. Стогний. - М., 2020. - № 3 (34). - С. 49-64.

13. Павлова (Черкасова) С.А. Содержание гимнографических текстов как основа их певческой интерпретации // Ученые записки Российской академии музыки имени Гнесиных / Ред. И.С. Стогний. - М., 2020. -№ 3 (34). - С. 92-106.

14. Рамазанова Н.B. Московское царство в церковно-певческом искусстве XVI-XVII веков. СПб.: «Дмитрий Буланин», 2004. - 453 с.

15. Ростовский Дмитрий, свт. Книги житий святых, 4-я четверть: Июнь - август. Киев: Тип. Киево-Печерской лавры, 1764. - 604 л.

16. Самбикин Дмитрий, архиеп. Месяцеслов святых, всей Русской церковью или местно чтимых и указатель празднеств в честь икон Божией Матери и св. угодников Божиих в нашем отечестве. - Каменец-Подольск: тип. Подол. губ. правл., 1893-1902. - Вып. 11: Июль. 1901. - 377 с.

17. Семененко-Басин И.В. Почитание русских святых: проект Афанасия Сахарова в историческом контексте // Культурная жизнь Юга России. -Краснодар: Краснодарский государственный институт культуры. - № 1 (30). - 2009. - С. 61-63.

18. Спасский Сергий, архиеп. Полный месяцеслов Востока. - М.: Церков.-науч. центр «Православ. энцикл.»: Православ. Паломник, 1997. - Т. 2: Святой Восток. XXX. - 398 с.

19. Срезневский И.И. Материалы для словаря древне-русскаго языка по письменным памятникам. - СПб.: издание Отд-ния рус. яз. и словесности Императорской акад. наук. - 1890-1906. - Т. 2: Л - П. 1895-1902. - 1802 с.

20. Фасмер М. Этимологический словарь русского языка: В 4 т. / Пер. с нем. и доп. О.Н. Трубачева. - 3-е изд., стер. - М.: Изд. центр «Терра», 1996. - T. 3. -830 c.

21. Черкасова С.А. Гимнография святителю Николаю: к вопросу о системе пения на подобен // Святитель Николай Мирликийский в памятниках письменности и иконографии / [отв. ред.-сост. Г.С. Клокова, М.С. Крутова]. - М.: Православный Свято-Тихоновский Гуманитарный Ун-т; Типография «Наука», 2006. С. 126-149.

22. Черкасова С.А. Русские службы Рождеству святителя Николая // Альфа и Омега. - М., 2008. - № 1 (51). - C. 285-298; № 2 (52). - С. 307-327. 